\title{
Geological and Isotopic Constraints on the Metallogenic Evolution of the Proterozoic Sediment- Hosted Pb-Zn (Ag) Deposits of Brazil
}

\author{
Aroldo Misi ${ }^{1}$, Sundaram S. Iyer ${ }^{2}$, Colombo C. G. Tassinari ${ }^{3}$, \\ J. Richard Kyle ${ }^{4}$, Carlos E. S. Coelho', Washington J. S. Franca-Rocha ${ }^{5}$, \\ Adriana S. R. Gomes ${ }^{5}$, Ioná A. Cunha ${ }^{5}$, and Ilson G. Carvalho ${ }^{6}$ \\ ${ }^{\prime}$ Centro de Pesquisa em Geofisica e Geologia (CPGG) and Instituto de Geociências, Universidade \\ Federal da Bahia, Salvador, BA 40210-340,Brazil, E-Mail: misi@ufba.br \\ ${ }^{2}$ Department of Physics and Astronomy, University of Calgary, Calgary, Alherta, T2N IN4, Canada \\ ${ }^{3}$ Centro de Pesquisas Geocronológicas, Instituto de Geociências, Universidade de São Paulo, São Paulo, \\ São Paulo, 05422-970, Brazil \\ ${ }^{4}$ Department of Geological Sciences, The University of Texas at Austin, Austin, Texas, 78712-1101, U.S.A. \\ ${ }^{5}$ Curso de Pós-Graduação em Geologia, Instituto de Geociências, Universidade Federal da Bahia, \\ Salvador, Bahia, 40210-340, Brazil \\ ${ }^{6}$ Curso de Pós-Graduação em Geoquímica, Instituto de Geociências, Universidade Federal da Bahia, \\ Salvador, Bahia, 40210-340, Brazil
}

(Manuscript received December 12, 1997; accepted June 26, 1998)

\begin{abstract}
Integrated studies of seven Proterozoic sediment-hosted, $\mathrm{Pb}-\mathrm{Zn}$-Ag sulfide deposits of Brazil, permit the estimation of the age of the hosting sequence and the mineralization, the nature of the sulfur and metal sources, the temperature range of sulfide formation and the environment of deposition. These deposits can be classified into three groups, according to their ages. (a) Archean to Paleoproterozoic: the Boquira deposit, in Bahia state, consists of stratiform massive and disseminated sulfides hosted by parametamorphic sequences of grunnerite-cummingtonite+magnetite that represent a silicate facies of the Boquira Formation (BF). Lead isotope data of galena samples indicate a time span between 2.7 and 2.5 $\mathrm{Ga}$ for ore formation, in agreement with the stratigraphic position of the BE. The relatively heavy sulfur isotope compositions for the disseminated and stratiform sulfides $(+8.3$ to $+12.8 \%$ CDT) suggest a sedimentary source for the sulfur. (b) Paleo to Mesoproterozoic: stratiform and stratabound sulfides in association with growth faults are present in the Canoas mine (Ribeira, in Paraná state) and in the Caboclo mineralization (Bahia state). They are hosted by calcsilicates and amphibolites in the Canoas deposit, whereas in the Caboclo area the mineralization is associated with hydrothermally altered dolarenites at the base of the $1.2 \mathrm{Ga}$ Caboclo Formation. The interpreted $\mathrm{Pb}-\mathrm{Pb}$ age of the Canoas mineralization is coeval with the 1.7 $\mathrm{Ga}$ host rocks. Sulfur isotopic data for Canoas sulfides $(+1.2$ to $+16 \%$ CDT) suggest a sea water source for the sulfur. The range between -21.1 and $+8.8 \%$ CDT for the Caboclo sulfides could suggest the action of bacterial reduction of seawater sulfates, but this interpretation is not conclusive. (c) Neoproterozoic: stratiform and stratabound sulfide deposits formed during the complex diagenetic history of the host carbonate rocks from the Morro Agudo (Bambui Group), Irecê and Nova Redenção (Una Group), yield heavy sulfur isotope values ( +18.9 to $+39.4 \%$ CDT). The uniform heavy isotope composition of the barites from these deposits $(+25.1$ to $+40.9 \%$ ) reflect their origin from Neoproterozoic seawater sulfates. The latestage, and most important, metallic concentrations represent sulfur scavenged from pre-existing sulfides or from direct reduction of evaporitic sulfate minerals. Lead isotope data from the Bambui Group suggest focused fluid circulation from diverse Proterozoic sediment sources, that probably was responsible for metal transport to the site of sulfide precipitation. (d) Late Proterozoic to Early Paleozoic: lead-zinc sulfides (+pyrite and chalcopyrite) of Santa Maria deposits, in Rio Grande do Sul, form the matrix of arkosic sandstones and conglomerates, and are closely associated with regional faults forming graben structures. Intermediate volcanic rocks are intercalated with the basal siliciclastic members. Lead isotope age of the mineralization $(0.59 \mathrm{Ga})$ is coeval with the host rocks. Sulfur isotopic values between -3.6 and +4.1 are compatible with a deep source for the sulfur.
\end{abstract}


Geological, petrographic and isotopic data of the deposits studied suggest that they were formed during periods of extensional tectonics. Growth faults or reactivated basement structures probably were responsible for localized circulation of metal-bearing fluids within the sedimentary sequences. Sulfides were formed by the reduction of sedimentary sulfates in most cases. Linear structures are important controls for sulfide concentration in these Proterozoic basins.

Key words: Sediment-hosted $\mathrm{Pb}-\mathrm{Zn}(\mathrm{Ag})$ deposits, Proterozoic, Brazil, isotopes, metallogeny.

\section{Introduction}

The Proterozoic Eon is characterized, on almost every continent, by its relatively higher abundance of base metal sulfide deposits. World-class lead-zinc and/or copper deposits are present in the Proterozoic sedimentary basins of most continental areas, such as: Broken Hill, McArthur and Mount Isa-Century districts, in Australia; Sullivan, in Canada; Gamsberg and Zambia-Congo copperbelt, in the African continent. These deposits contain huge reserves, with total metal content exceeding 250 million tonnes. In contrast, such dcposits have not been discovered in the South American continent until now. In Brazil, representing almost half of the entire continental area, there are no large base-metal sulfide deposits despite the widespread occurrence of Proterozoic sedimentary basins covering more than $500,000 \mathrm{~km}^{2}$ of its territory. Except for the Morro Agudo-
Vazante mines, in the state of Minas Gerais (2 to 3 million tonnes of $\mathrm{Zn}+\mathrm{Pb}$ metal content), there are only small deposits and occurrences distributed in these Proterozoic basins.

The main question at this point is: why are no worldclass Proterozoic sediment-hosted sulfide deposits present on the South American continent? The answer to this question may be the inadequate investment in mineral exploration by mining companies and/or lack of satisfactory metallogenic models that could be employed for exploration planning. In any case, there is a consensus among geologists from the academic institutions and mining companies concerning the absence of adequate information that cuuld be used for constructing consistent metallogenic models.

In this paper we discuss the preliminary results of our on-going investigation of seven Z $\mathrm{n}-\mathrm{P} \mathrm{b}$ - Ag sediment-hosted sulfide deposits in Brazil, covering a time span from

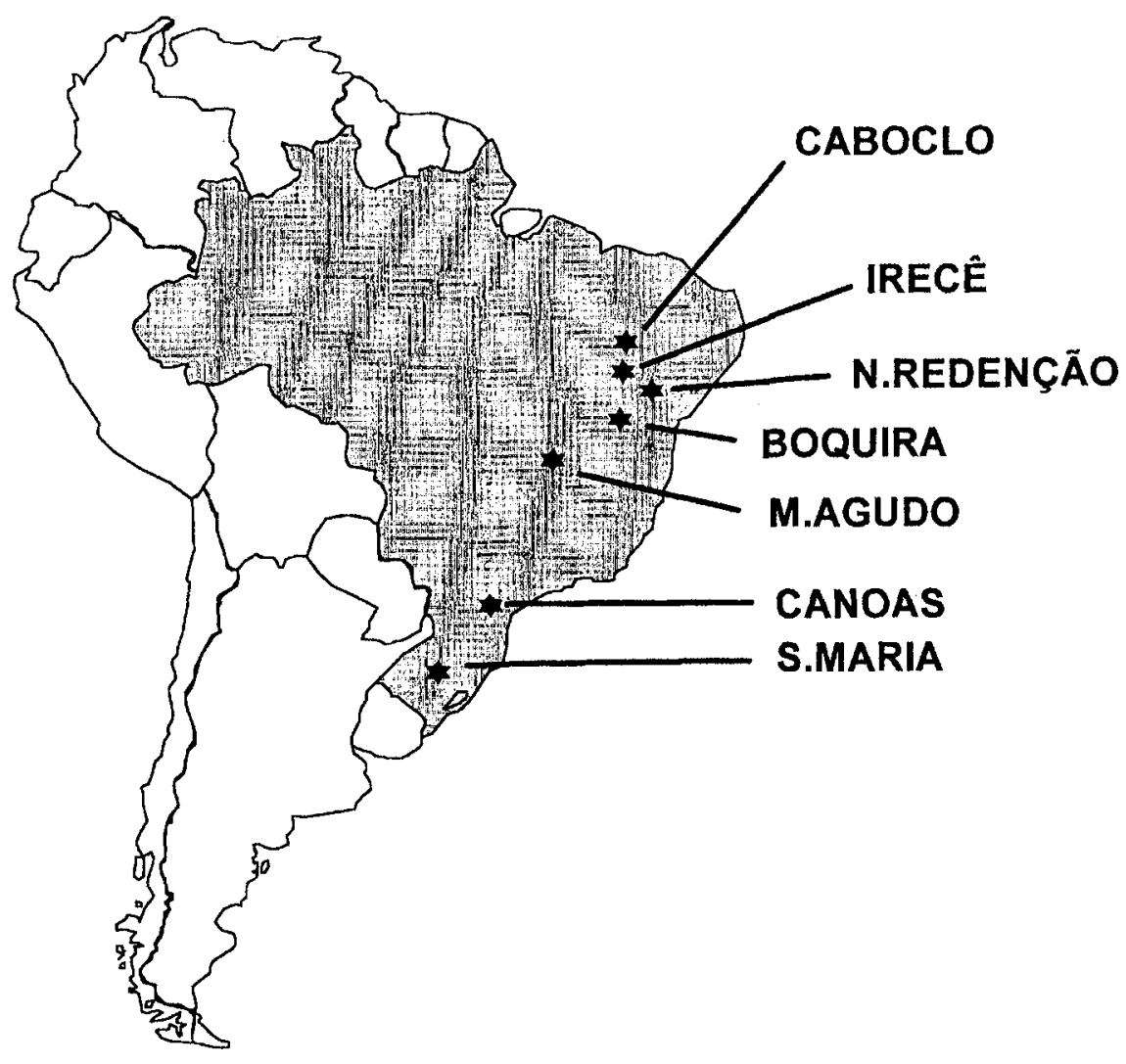

Fig. 1. Location of the Brazilian Proterozoic sediment-hosted Zn-Pb-Ag sulfide deposits studied. 
approximately $2.5 \mathrm{Ga}$ to $0.57 \mathrm{Ga}$. These deposits are: Boquira, Caboclo, Irecê and Nova Redenção, in the state of Bahia; Morro Agudo, in Minas Gerais state; Canoas in Paraná and Santa Maria, in Rio Grande do Sul state (Fig. 1). In these deposits geological, petrographical and geochemical data, along with radiogenic and stable isotope signatures and fluid inclusions studies, are being employed to interpret their geotectonic setting and trace the metallogenic evolution. It is our firm belief that an integrated and adequate interpretation of these data should certainly open new perspectives for base-metal exploration in the Proterozoic sedimentary basins of Brazil.

All the deposits studied have been described earlier and mapped by the authors and/or by others. The deposits of Boquira, Caboclo, Irecê, Nova Redenção and Morro Agudo are being studied since 1987, by the Research Group on "Metallogenesis and Mineral Deposits Modeling", from the $\mathrm{CNPq}$ (the National Research Council of Brazil) and the University of Bahia, Brazil, in collaboration with other national and international research centers. They have also been mapped respectively by Fleischer (1976), Conceição Filho and Silva_1984), Monteiro et al. (1987), Moraes Filho and Leal (1990) and Dardenne (1978a). Though the deposits of Canoas and Santa Maria have been visited and sampled by two of the authors, the main research work is being carried out, respectively, at the Universities of São Paulo and Estadual Paulista at Rio Claro (Tassinari et al., 1990; Daitx, 1996) and at the University of Rio Grande do Sul (Badi, 1983; Remus et al., 1997). Much of the information on these two deposits are taken from the works cited above. Many Brazilian mining companies and institutions, such as Companhia Baiana de Pesquisa Mineral (CBPM), Companhia de Pesquisa de Recursos Minerais (CPRM), Companhia Mineira de Metais (CMM), Companhia Brasileira do Cobre ( $C B C$ ), Plumbum Mineração e Metalurgia and Departamento Nacional da Produção Mineral (DNPM), also contributed to the geological characterization of the deposits studied.

\section{Sampling Methods and Analytical Techniques}

Host rocks, sulfides and gangue minerals, especially sulfates, were sampled for their multiple variations of facies and morphology. Rock samples were systematically selected for petrography and fluid inclusions studies. Ore and gangue minerals for geochemical and isotopic determinations were separated in the laboratory by hand picking under a binocular microscope and by heavy liquid separation methods.

Most stable isotope analyses were carried out at the Stable Isotope Laboratory of the University of Calgary, Canada, following procedures described by Iyer et al. (1992). For the sulfur isotope analysis, $\mathrm{SO}_{2}$ was liberated from a $\mathrm{SiO}_{2}-\mathrm{V}_{2} \mathrm{O}_{5}$ sample mixture in on-line vacuum extraction system coupled to a mass spectrometer built using Micromass 602 components. The precision of analysis was $\pm 0.2 \%$. Analysis from the sulfides and sulfates of Irecê were partially performed in the laboratory of W.C.Shanks III, at the U.S. Geological Survey in Reston, Virginia, with a precision and accuracy within $\pm 0.2 \%$, and partially in a commercial isotope facility that reports the data to be accurate within \pm $0.5 \%$. Stable isotopes from the Caboclo deposit (including $\mathrm{C}$ and $\mathrm{O}$ from the carbonate host rocks) were analysed at the University of Ottawa, using a mass spectrometer VG ISOGAS SIRA 12. The precision of analysis was $\pm 0.1 \%$. The $\delta^{34} \mathrm{~S}$ values are reported relative to Canon Diablo Troilite (CDT) and the $\delta^{13} \mathrm{C}$ and $\delta^{18} \mathrm{O}$ results to the Pee Dee Belemnite standard (PDB).

The lead isotope analyses were performed at the Geochronology Research Center of the University of São Paulo, Brazil. Galena crystal aggregates were washed in distilled water to remove any fine impurity adhered to the surface and then powdered and dissolved in distilled $10 \mathrm{~N}$ $\mathrm{HCl}$. The lead isotope analyses were carried out using the single filament silica-gel method in a VG 354 Micromass mass spectrometer. The precision and accuracy (verified using NBS lead standards 981 and 982) was of the order of $\pm 0.1 \%$. The model lead ages are calculated through the Lead Isotope Evolution by a two stage model (Stacey and Kramers, 1975).

Fluid inclusion studies were perfomed at the University of Bahia and University of Brasilia, using a Chaixmecca heating-freezing stage fixed to a Nikon microscope equipped with a $100 \mathrm{X}$ objective. Calibration of the apparatus was performed using synthetic fluid inclusions from Fluid Inc. Precision of determinations was $\pm 0.1^{\circ} \mathrm{C}$ in the temperature range of the observed phase changes. Estimated accuracy between $-56.6^{\circ} \mathrm{C}$ and $0^{\circ} \mathrm{C}$ was $\pm 0.2^{\circ} \mathrm{C}$ and above $+100^{\circ} \mathrm{C}$, around $1.0-1.5^{\circ} \mathrm{C}$.

\section{General Characteristics of the Deposits}

Table 1 shows the main geological characteristics of the deposits studied. All have massive and/or disseminated stratiform+stratabound and vein type mineralization, and show remarkable stratigraphic control. Sphalerite, galena and pyrite, along with barite, calcite and quart $z$ are present in varying amounts, except in Boquira $(\sim 2.5 \mathrm{Ga})$ and in Caboclo, where barite has not been found. Silver content is generally high in all the deposits studied. Sulfide mineralization is clearly associated with faults in Canoas, Caboclo, Morro Agudo, Nova Redenção and Santa Maria. In the other deposits this association is not evident.

Reserves and metal grades are indicated in Table $2 . \mathrm{Pb}-$ isotope data are given in Table 3. Of the deposits listed, 
Table 1. General characteristics of the sediment-hosted sulfide deposits of Brazil studied.

\begin{tabular}{|c|c|c|c|c|c|c|c|}
\hline NAME & MORPH & $\begin{array}{c}\text { ORE } \\
\text { MINER. }\end{array}$ & GANGUE & $\begin{array}{c}\text { HOST } \\
\text { ROCKS }\end{array}$ & $\begin{array}{l}\text { STRUCT. } \\
\text { ASSOC. }\end{array}$ & $\begin{array}{c}\text { AGE OF } \\
\operatorname{HOST}(\mathrm{Ga})\end{array}$ & $\begin{array}{l}\text { AGE OF } \\
\text { MIN.(Ga) }\end{array}$ \\
\hline $\begin{array}{l}\text { STA. } \\
\text { MARIA } \\
\text { (RS) }\end{array}$ & $\begin{array}{l}\text { Dissem. } \\
\text { Amas } \\
\text { Stratab. } \\
\text { Veins }\end{array}$ & $\begin{array}{l}\text { pyr, sph, } \\
\text { gal, (Ag) }\end{array}$ & $\begin{array}{l}\text { qz, } \\
\text { microcl, } \\
\text { albite, } \\
\text { moscov, } \\
\text { apatite, } \\
\text { biotite, } \\
\text { tourmal. }\end{array}$ & $\begin{array}{l}\text { Arkosic } \\
\text { sandst., } \\
\text { siltstones } \\
\text { and } \\
\text { conglom. }\end{array}$ & $\begin{array}{l}\text { Faults NE- } \\
\text { SW }\end{array}$ & 0.57 & 0.57 \\
\hline $\begin{array}{l}\text { IRECÊ } \\
\text { (BA) }\end{array}$ & $\begin{array}{l}\text { Dissem. } \\
\text { Amas } \\
\text { Stratab. } \\
\text { Veins }\end{array}$ & $\begin{array}{l}\text { sph+Ag, } \\
\text { pyr, gal, } \\
\text { jordanite }\end{array}$ & $\begin{array}{l}\text { calcite, } \\
\text { dolomite, } \\
\text { quartz, } \\
\text { chert, } \\
\text { barite, } \\
\text { gypsum, } \\
\text { barr.dol. }\end{array}$ & $\begin{array}{l}\text { Dolaren. } \\
\text { (silicified) }\end{array}$ & $?$ & $0.60-0.65$ & $\begin{array}{c}0.60- \\
0.65 \\
(?)\end{array}$ \\
\hline $\begin{array}{c}\text { NOVA } \\
\text { REDEN- } \\
\text { ÇÃO (BA) }\end{array}$ & $\begin{array}{l}\text { Amas } \\
\text { Veins } \\
\text { Stratab. }\end{array}$ & $\begin{array}{l}\text { gal, sph, } \\
\text { pyr, (Ag) }\end{array}$ & $\begin{array}{l}\text { qz, chert, } \\
\text { calcite, } \\
\text { dolomite, } \\
\text { barite }\end{array}$ & $\begin{array}{l}\text { Silicified } \\
\text { dolaren. }\end{array}$ & $\begin{array}{l}\text { Faults } \\
\text { NW-SE }\end{array}$ & $0.60-0.65$ & $\begin{array}{c}0.60- \\
0.65 \\
(?)\end{array}$ \\
\hline $\begin{array}{l}\text { MORRO } \\
\text { AGUDO } \\
\text { (MG) }\end{array}$ & $\begin{array}{c}\text { Stratifor. } \\
\text { Veins }\end{array}$ & $\begin{array}{l}\text { gal, sph, } \\
\text { pyr, (Ag) }\end{array}$ & $\begin{array}{l}\text { calcite, } \\
\text { dolomite }\end{array}$ & $\begin{array}{l}\text { Dolaren. } \\
\text { Dolosilt. }\end{array}$ & $\begin{array}{c}\text { Faults } \\
\mathrm{N}-\mathrm{S}\end{array}$ & $0.60-0.65$ & 0.65 \\
\hline $\begin{array}{l}\text { CABO- } \\
\text { CLO (BA) }\end{array}$ & $\begin{array}{c}\text { Stratab. } \\
\text { Veins }\end{array}$ & $\begin{array}{c}\text { gal, (Ag), } \\
\text { pyr }\end{array}$ & $\begin{array}{l}\text { calcite, } \\
\text { dolomite, } \\
\text { barr.dol., } \\
\text { qz., } \\
\text { microcl., } \\
\text { albite, } \\
\text { moscovit } \\
\text { e tourmal. }\end{array}$ & Dolaren. & $\begin{array}{c}\text { Growth } \\
\text { Faults } \\
\text { N-S }\end{array}$ & 1.2 & $1.2(?)$ \\
\hline $\begin{array}{l}\text { CANOAS } \\
\text { (SP) }\end{array}$ & $\begin{array}{l}\text { Stratifor. } \\
\text { Veins }\end{array}$ & $\begin{array}{l}\text { gal., sph. } \\
\text { pyr, pyrr. } \\
(\mathrm{Ag})\end{array}$ & $\begin{array}{l}\text { barite, } \\
\text { qz., chert, } \\
\text { amphib. }\end{array}$ & $\begin{array}{l}\text { Amphibo- } \\
\text { lite, Calc- } \\
\text { silicate }\end{array}$ & $\begin{array}{c}\text { Growth } \\
\text { Faults } \\
\text { NE-SW }\end{array}$ & $1.5-1.7$ & $1.5-1.7$ \\
\hline $\begin{array}{c}\text { BOQUIRA } \\
\text { (BA) }\end{array}$ & $\begin{array}{l}\text { Stratifor. } \\
\text { Dissem. } \\
\text { Veins }\end{array}$ & $\begin{array}{l}\text { gal, sph, } \\
\text { pyr, pyrr, } \\
\text { (Ag) }\end{array}$ & $\begin{array}{l}\text { amphib., } \\
\text { magnet., } \\
\text { gz. }\end{array}$ & $\begin{array}{l}\text { Amphibo- } \\
\text { lite, Car- } \\
\text { bonate }\end{array}$ & $?$ & 2.7 & $2.5-2.7$ \\
\hline
\end{tabular}

Morro Agudo is the only mine in operation at present, producing 500,000 tonnes/year (run-of-mine). Boquira was the most important lead mine of Brazil for many years, until 1991, when the mining operation ceased due to lack of proven reserves. The mine produced approximately six million tonnes of ore $(9 \% \mathrm{~Pb}$ and $2 \% \mathrm{Zn})$ for about 40 years.

The deposits studied are grouped into four classes based on their ages:
Archean to Paleoproterozoic

Boquira

The Boquira $\mathrm{Pb}-\mathrm{Zn}$ deposit has been previously studied by Fleischer (1976), Espourteille and Fleischer (1988), Carvalho (1982, 1985), Carvalho et al. (1982), and Rocha (1990). Recently, geological and petrographical observations combined with lead and sulfur isotope investigations, led 
Table 2. Reserves and metal grades of the deposits.

\begin{tabular}{|c|c|c|c|c|}
\hline \multirow[t]{2}{*}{ Deposit } & \multirow[t]{2}{*}{ Tot. Reserves $(t)$} & \multicolumn{3}{|c|}{ Metal Grades } \\
\hline & & $\mathrm{Pb}(\%)$ & $\operatorname{Zn}(\%)$ & $\operatorname{Ag}(g / t)$ \\
\hline S. Maria & 46.000 .000 & 1.3 & 0.9 & 12 \\
\hline M. Agudo & 11.700 .000 & 2.2 & 6.4 & \\
\hline Irecê & 1.500 .000 & - & 7.9 & 120 \\
\hline N. Redenção & 2.500 .000 & 6.3 & 0.5 & 33 \\
\hline Canoas & 1.500 .000 & 3.5 & 3.5 & 60 \\
\hline
\end{tabular}

Table 3. Pb isotope data for the deposits studied.

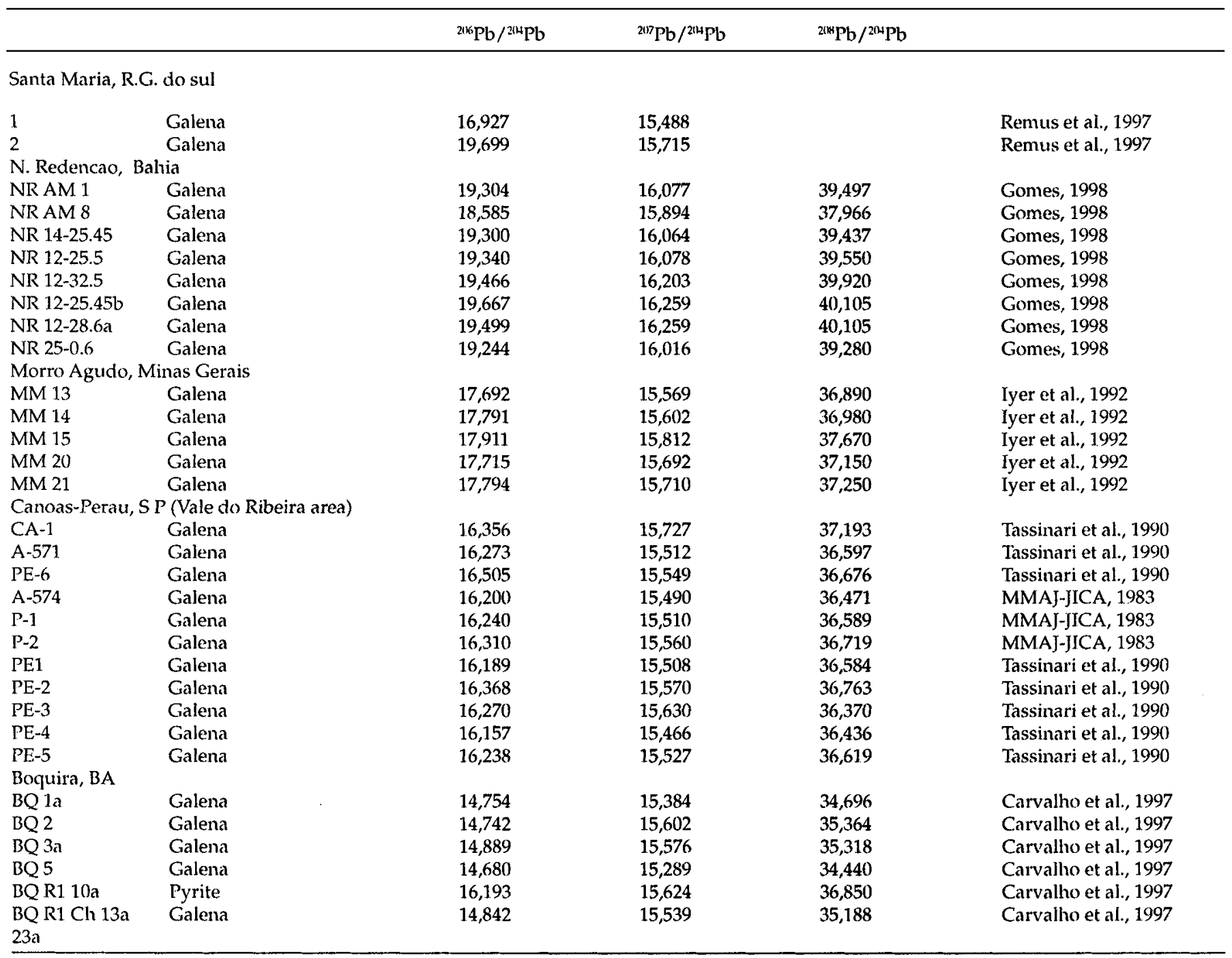

Misi et al. (1996) and Carvalho et al. (1997) to propose a sedimentary model for the metal concentration.

The lead-zinc sulfide mineralization of Boquira is hosted by parametamorphic sequences lying along a N-S linear zone in the central part of the São Francisco Craton. Stratiform massive sulfides, composed of galena, sphalerite, magnetite, maghemite, amphiboles, pyrrhotite, pyrite, quartz and minor chalcopyrite, are hosted by banded grunnerite-cummingtonite+magnetite facies, a silicate facies of the Boquira Formation (BF). Mesoproterozoic siliciclastic sedimentary sequences, intercalated with acidic to intermediate volcanic rocks $(1.7 \mathrm{Ga})$, overlie the BF. The Boquira Formation is isoclinally folded with infolding in the Archean basement rocks of $2.8 \mathrm{Ga}$ (Figs. 2 and 3 ). 


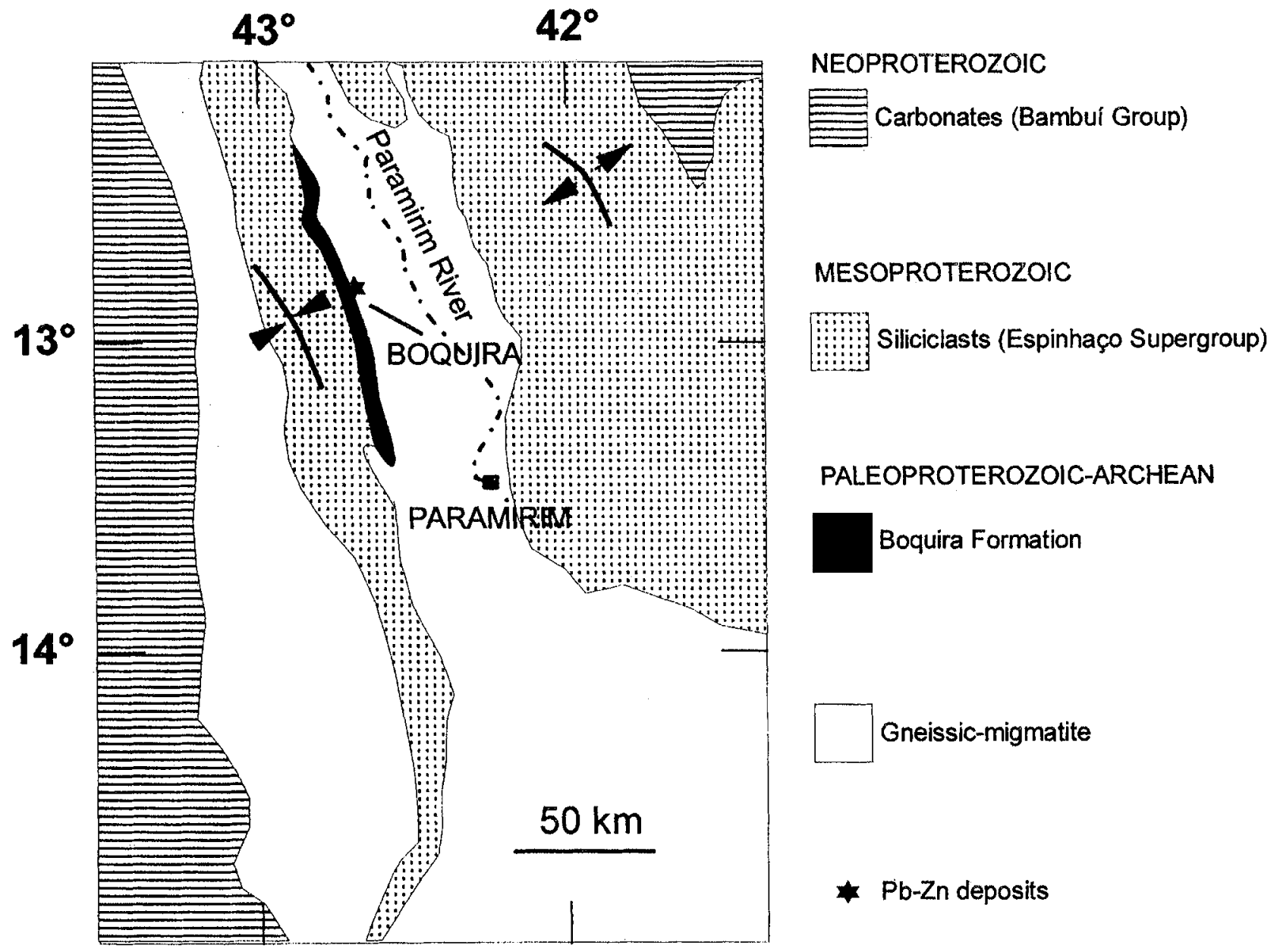

Fig. 2. Simplified geological map of the Boquira area, in Bahia state. From Carvalho et al. (1997), modified.

Lead isotope data of six galena samples from the stratiform mineralization were plotted in ${ }^{207} \mathrm{~Pb} /{ }^{204} \mathrm{~Pb}$ vs ${ }^{206} \mathrm{~Pb} /{ }^{204} \mathrm{~Pb}$ curves and the data were interpreted according to classical plumbotectonic two stage model of Zartman and Doe (1981). The calculated model age values indicate a time span between $2.7 \mathrm{Ga}$ and $2.5 \mathrm{Ga}$ for the formation of the stratiform sulfides. Previous lead-isotope data for three galena samples from Boquira by Cassedanne (1966), yielded a $\mathrm{Pb}-\mathrm{Pb}$ model age of $2.5 \mathrm{Ga}$. The radiogenic isotope composition and large variation in ${ }^{207} \mathrm{~Pb} /{ }^{204} \mathrm{~Pb}$ data $(15.28$ to 15.53), is a phenomenon expected in galenas of Archean age and is due to the accumulation of larger amounts of ${ }^{207} \mathrm{~Pb}$ as compared to ${ }^{206} \mathrm{~Pb}$ stemming from the different decay constants of ${ }^{235} \mathrm{U}$ and ${ }^{238} \mathrm{U}$. In the plumbotectonic model curves of Zartman and Doe (1981), the data points fall above the evolution curve for upper crust, suggesting an upper crustal source for the lead. According to Iyer et al. (1992), the non-radiogenic character of the lead is an indication that the major part of it could have come from feldspars, probably from the basement rocks. The possibility of multiple sources with different $\mathrm{U} / \mathrm{Pb}$ and $\mathrm{Th} / \mathrm{Pb}$ values should not be discarded, considering the oblique distribution of analytical data points. The sulfides carried U-bearing phases in close association or as inclusions, as can be seen from the high $\mu_{1-}$ values (12.22 to 14.91).

The $\delta^{34} \mathrm{~S}$ values for the primary sulfides are in the range of +8.3 to $+12.8 \%$. Pyrite and pyrrhotite from veins (remobilized) yielded values of +3.7 and $+10.4 \%$, respectively. These high positive $\delta^{34} S$ values, rule out the possibility of a deep mantle source for the sulfur. On the other hand, the $\delta^{34} S$ values for the Boquira sulfides are in the same range as those of Paleoproterozoic sea water (Strauss, 1993). Thus, the sulfur isotope data suggest a marine source for the sulfur. Applying the equation of Ohmoto and Rye (1979) for the sulfide-isotope geothermometer to a galena-sphalerite cogenetic pair $\left(\delta^{34} \mathrm{Sgal}=+10.7 \%\right.$ and $\left.\delta^{34} \mathrm{Ssph}=+12.6 \%\right)$, a temperature of $350 \pm 20^{\circ} \mathrm{C}$ is obtained. Using the geothermometric equation of Bortnikov et al. (1995) for the Cd content for a galena (140ppm Cd) and sphalerite ( $1 \% \mathrm{Cd}$ ) pair (Espourteille and 


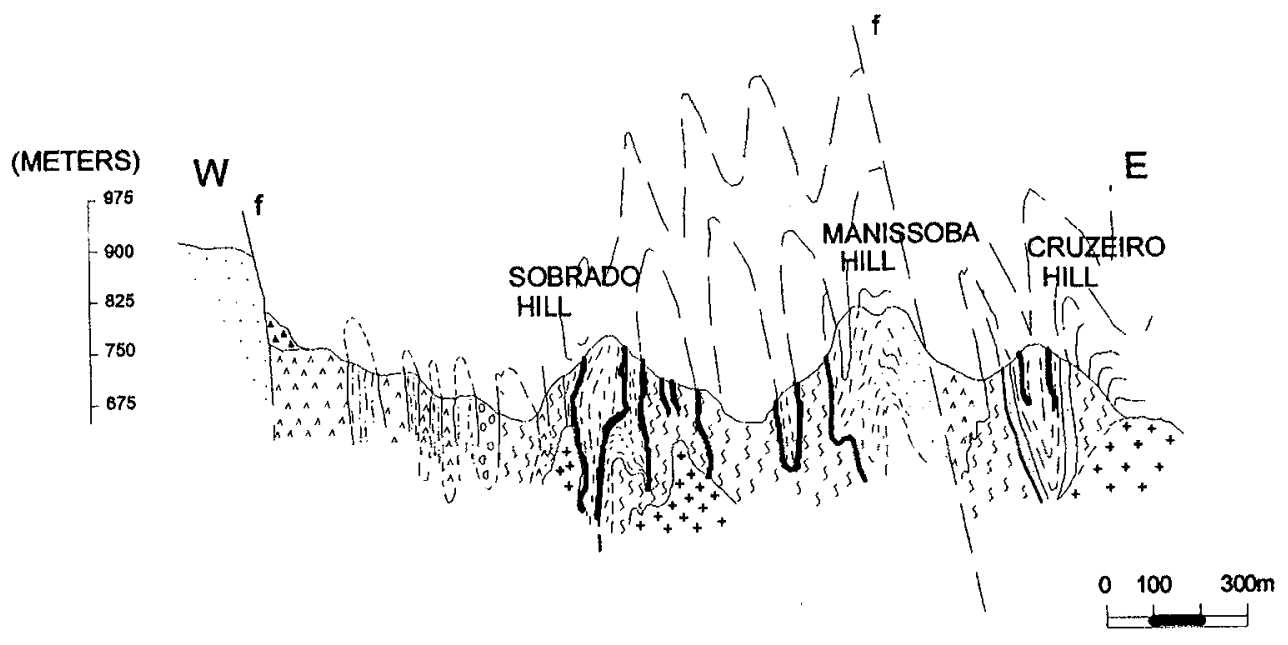

EXPLANATION

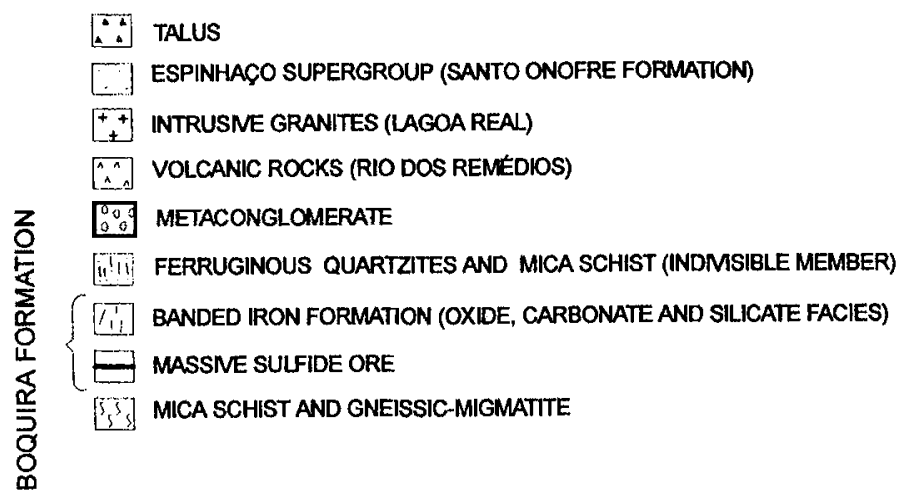

Fig. 3. Cross section of the Boquira mineralization, modified after Espourteille and Fleischer (1988) and Carvalho et al. (1997).

Fleischer, 1988), a temperature of $370 \pm 20^{\circ} \mathrm{C}$ is also obtained, This suggest the possibility of a thermochemical reduction of sulfates to form the sulfides.

Although much work has to be done in the Boquira deposit, including fluid inclusions thermometry and composition, the available data are consistent with the sediment-hosted massive sulfide model (Large, 1983).

Paleoproterozoic to Mesoproterozoic

Canoas

Major studies dealing with the Canoas deposits are those by Fleischer (1976), Tassinari et al. (1990) and Daitx (1996). Daitx (1996) carried out a detailed study of the deposits of the Vale do Ribeira area that included stable and radiogenic isotope determinations of host rocks and ore minerals.

Host rocks in the Canoas deposit are limestones and dolomites, containing phlogopite, tremolite and diopside, of the Mesoproterozoic Perau Complex (1.5 to $1.7 \mathrm{Ga}$ ). The $\mathrm{Pb}-\mathrm{Zn}$ stratabound mineralization is present in a $7 \mathrm{~m}$ thick bed, cut by normal faults in two different places to form the deposits 1,2 and 3. These deposits are oriented N50E and dip 6 to $9^{\circ}$ Northwest. Mineralization is mainly formed by banded and disseminated or massive galena, sphalerite, pyrite, pyrrhotite and chalcopyrite and subordinate tetrahedrite, freibergite, pyrargirite, polybasite, stephanite, argentite, arsenopyrite, marcasite, millerite and violarite. Barite and quartz are also present in variable amounts. Breccia type mineralized structures are also found in the Canoas deposit. They were interpreted by Daitx (1996) as fragmented or deformed banded host rocks, cemented by the sulfide mineralization.

The interpreted $\mathrm{Pb}-\mathrm{Pb}$ model age of the mineralization is coeval with the $1.7 \mathrm{Ga}$ host rocks (Tassinari et al, 1990, Daitx, 1996). The lead isotope data plot above the upper crust curve of the plumbotectonic model of Zartman and Doe (1981), suggesting the probable derivation of metals from the basement rocks of the Perau Basin.

The $\delta^{34} \mathrm{~S}$ values for 9 sulfide samples (pyrite, galena and sphalerite) of the stratabound mineralization, (5 samples from Daitx, 1996), gave positive values, between +1.2 and 
$+16 \%$ CDT (mean of $+5.3, \mathrm{n}=9$ ). Three barite samples analysed by Daitx (1996) show high positive values of +20.6 , +21.5 and $+22.2 \%$. Sulfur isotopic data of sulfides and sulfates are consistent with a sea water source for the sulfur.

\section{Caboclo}

The Caboclo deposit has been studied by Companhia de Pesquisa de Recursos Minerais (CPRM) (Neves et al., 1980) and Companhia Baiana de Pesquisa Mineral (CBPM) (Conceição Filho and Silva, 1984; Conceição Filho et al., 1986). More recently, Franca Rocha (1995) and Franca Rocha and Misi (1992,a, b, 1993) presented the results of detailed geological and geochemical studies of the deposit, including stable isotope determinations of sulfides and host rocks.

The Caboclo lead silver-rich deposit, is hosted by dolomite lenses occurring in the basal portion of the siliciclastic marine sequences (mainly pelitic) of the Caboclo Formation. Mineralization is associated with extensional faults aligned NNE-SSW (Fig. 4). This formation belongs to the Chapada Diamantina Group, a $2000 \mathrm{~m}$ Mesoproterozoic sedimentary pile composed of three units: Tombador Formation, formed of fluvial and eolic
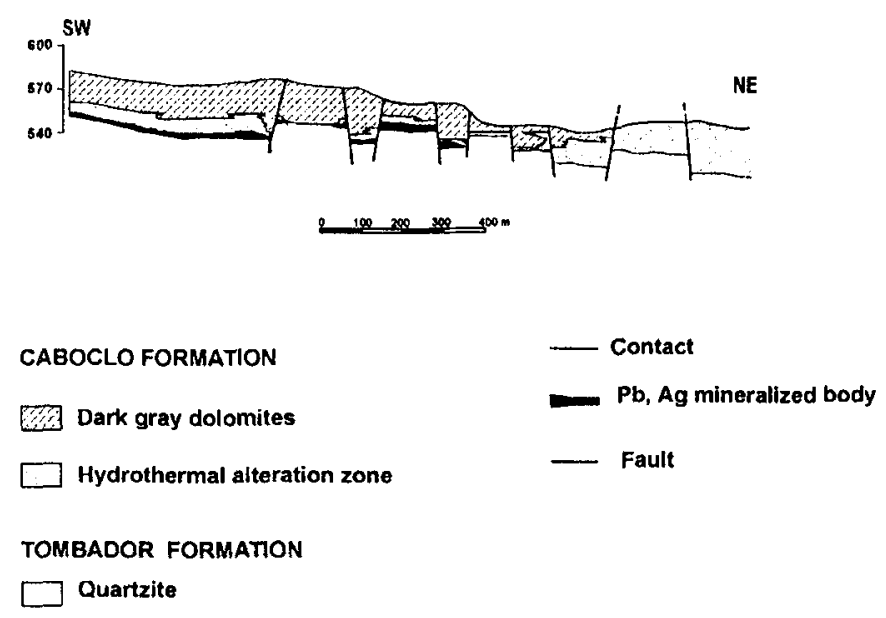

Fig. 4. Cross section of the Caboclo mineralized area, modified after Conceição Filho et al. (1993).

conglomerates and quartzites, Caboclo Formation, mainly pelites with subordinate carbonate lenses, and Morro do Chapeu Formation, composed of dominant continental facies (fluvial and eolic), with marine incursions in the upper section. $\mathrm{Pb}-\mathrm{Pb}$ isochronic age for the pelites of the Caboclo Formation (Babinski et al., 1993), is $1.14 \pm 0.14 \mathrm{Ga}$. The origin of the intracratonic rifting basin of the Chapada Diamantina Group is probably related to a thermo-flexural subsidence (Kiang et al., 1988), as indicated by the existence of NWtrending basic dykes that are intrusive into the Tombador
Formation and into the basal portion of the Caboclo Formation (Corrêa Gomes et al., 1996).

Sulfide mineralization in the Caboclo area is composed mainly of stratabound, medium to fine grained galena, with minor chalcopyrite, within dolarenites and/or dololutites. Quartz veins with coarse-grained galena are also present, indicating remobilized stages of the mineralization. The stratabound mineralization forms a "zebra-type" structure, in which clear bands, composed of quartz and feldspar, alternate with dark bands containing muscovite, biotite, $\mathrm{K}$ feldspar, plagioclase, quartz, tourmaline and baroque dolomite. Galena is associated with the dark bands and forms small lenses or veinlets.

Conceição Filho et al. (1986), Davidson (1985), FrancaRocha and Misi (1993) and Franca-Rocha (1995), demonstrated the structural control of the mineralization, associated with faults aligned NE-SW. These faults have a clear extensional tectonic origin and are attributed to growth faults as suggested (among others) by the systematic observation of syn-sedimentary slumping structures in the carbonates, when in contact with these faults.

Host rocks immediately in contact with the stratabound sulfide mineralization are composed of hydrothermally altered dolarenites and dololutites, with irregular crystal aggregates and veinlets of quartz, microcline, plagioclase, muscovite, biotite, tourmaline and baroque dolomite. This anomalous paragenesis of the Caboclo Formation forms a $10 \mathrm{~m}$ wide zone around the stratabound sulfide mineralization.

Carbon isotopic variation from a mineralized section of the Caboclo dolarenite/dololutite, indicates a progressive decrease in $\delta^{13} \mathrm{C}$ values toward the mineralized zone: from +1.4 to $-5.3 \%$ PDB. The oxygen isotopic variation of the same samples indicates a very narrow range of low $\delta{ }^{18} \mathrm{O}$ values, between -16.0 and - $19.7 \%$ PDB (Fig. 5). When compared with "normal" or unaltered carbonates from the Caboclo Formation, away from the mineralized area, the carbon and oxygen isotope variations show a very distinctive pattern between the two areas. As indicated in Fig. 6, carbonate lithofacies of the mineralized area show very low $\delta^{13} \mathrm{C}$ and $\delta^{18} \mathrm{O}$, while barren dolarenites from the same unit show a narrow range of much heavier values, compatible with those expected for Proterozoic platform marine carbonates (Veizer and Hoefs, 1976; Veizer et al., 1990).

Eight galena samples from the Caboclo mineralization have been analyzed for the $\delta^{34} S$ compositions. Six samples from the stratabound galena show a wide range, between 21.1 and $+8.8 \%$ CDT and two samples of megacrystalline galena within quartz veins, indicate $+5.3 \%$ for both samples. This large variation for the stratabound galenas, with high negative values, could be suggestive of bacterial 


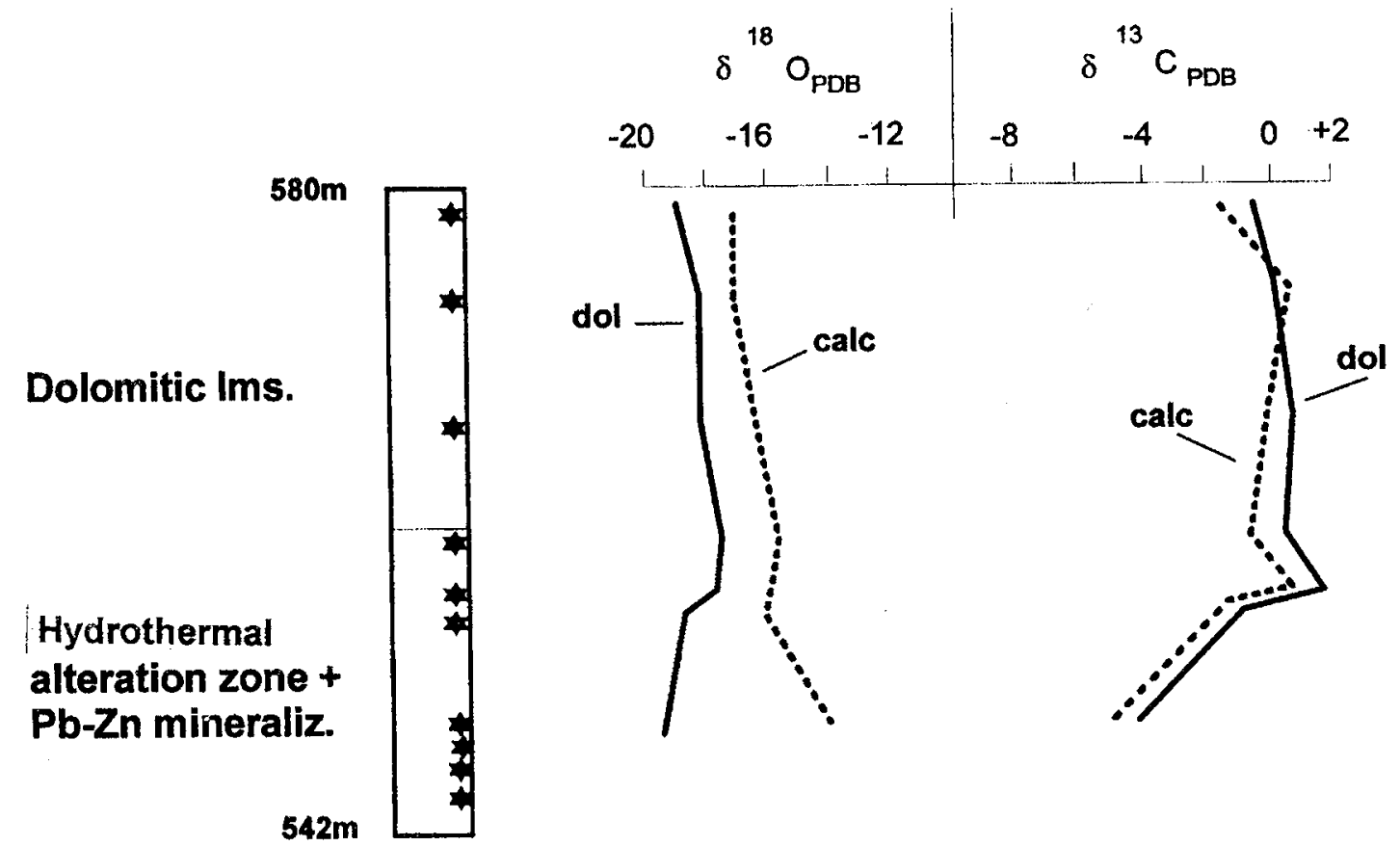

Fig. 5. Carbon and oxygen isotope variation along a mineralized section, in the Caboclo deposit. Variation for calcite (calc) and dolomite (dol) phases are indicated. After Franca-Rocha (1995).

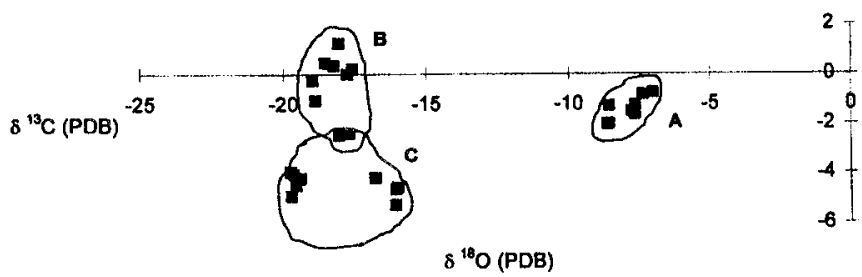

Fig. 6. Carbon and oxygen isotope variation of carbonates from the Mesoproterozoic Caboclo Formation. Field A: "Normal" dolomites from non mineralized areas. B: Dolomites from the Caboclo deposit, above the mineralized zone. C: Hydrothermal altered dolomites hosting the mineralization

reduction of sea water sulfates. However, this interpretation is not conclusive and should be treated with caution, due to the lack of other evidences, such as $\delta^{34} S$ data from barite or other sulfates (not found in the Caboclo area). The possibility of a mixing source for the sulfur, with a magmatic source as one of the end members, cannot be discarded, considering the favourable tectonic environment.

Neoproterozoic

Morro Agudo

The Morro Agudo deposit, discovered in 1961, was mapped and described by Dardenne (1976) and Bez (1979) before the beginning of mining operation, that began in 1982. Romagna and Costa $(1988,1989)$ described the deposit based on surface and underground mapping. Detailed petrographic and isotopic studies, as well as fluid inclusions thermometry and composition investigations (now in progress) are being carried out by the present authors. Some of the data were already discussed in extended abstracts by Cunha and Misi (1995) and Misi et al. (1996). These and additional data are presented here.

The Morro Agudo mineralization is associated to a 300 $\mathrm{km}$ N-S linear trend, where the Vazante mine and several small lead-zinc occurrences are located (Fig. 7). The Vazante mine, the largest zinc mine of Brazil (8 million tonnes, $23 \%$ $\mathrm{Zn}$ ), is situated about $80 \mathrm{~km}$ south of Morro Agudo. The deposit is essentially formed by willemite and calamine, in brecciated structures or in veins or lenses. The Morro Agudo and Vazante deposits are controlled by a N-S normal fault system dipping 20 to 70 degrees to the west. They have also a well defined stratigraphic control: The mineralization is confined to dolarenites from supratidal facies of the Vazante Formation. This formation was defined by Dardenne (1978b), who identified a cyclic organization in the siliciclastic-carbonate package, with two regressive megacycles separated by a transgressive event, very similar to the cyclic organization observed in the Bambui and Una Groups (Marini et al., 1984; Misi, 1978). Thickness is variable and may reach more than $2500 \mathrm{~m}$ in the southern part of the Vazante mine (Marini et al., 1984). The age of the Vazante Formation has been a matter of controversy for many years. Although considered the non cratonic, folded counterpart of the Bambuì Group by most researchers, Dardenne (1978b, 1979) did not find lithostratigraphic correlations with the typical cratonic BambuI sequences and suggested a 


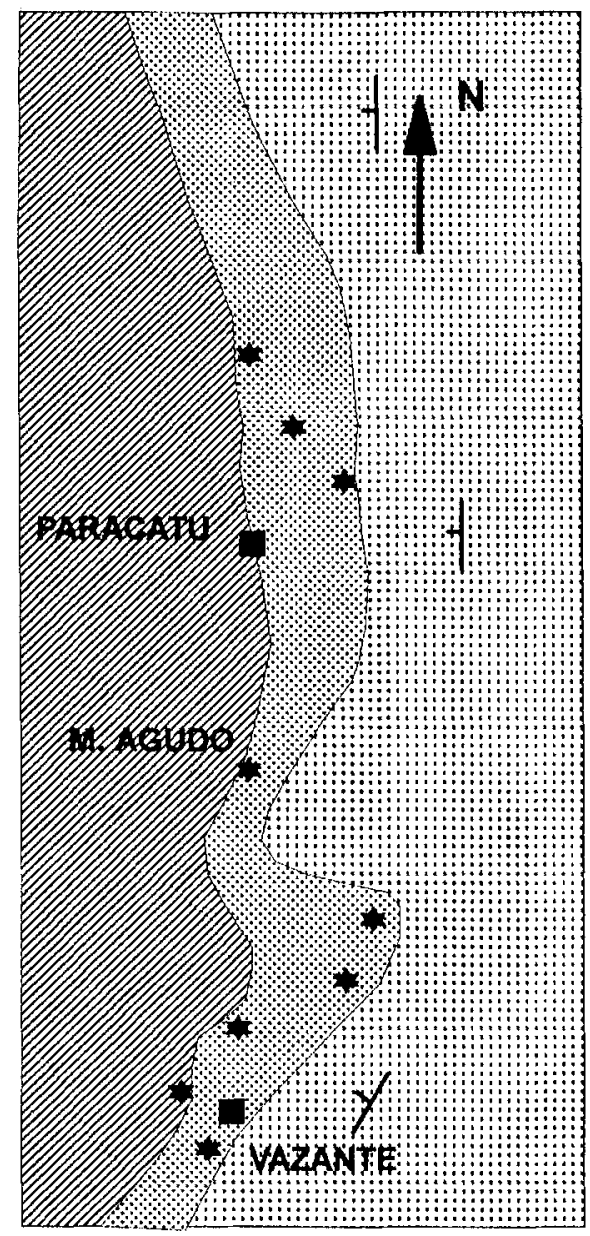

BLACK, GREEN SLATES (SERRA DO GARROTE Fm.)

\section{DOLOMITE}

(VAZANTE Fm.)

CARBONATIC SCHISTS, QUARTZITES (PARACATU Fm.)

\section{* ORE DEPOSITS AND MINERALIZATIONS}

\section{$50 \mathrm{KM}$}

Fig. 7. Simplified geological map of the Morro Agudo-Vazante Zn-Pb deposits (Neoproterozoic), in Minas Gerais state, modified after Rigobello et al. (1988).

Mesoproterozoic age for the Vazante Formation. However, recent chemostratigraphic studies carried out in the Una and Bambuí/Vazante sequences, based on ${ }^{87} \mathrm{Sr} /{ }^{86} \mathrm{Sr}$ determinations of well preserved carbonate samples (organic, micritic limestones) and of phosphorites (Misi et al., 1997), confirm the correlation between these sequences and suggest a terminal Proterozoic age $(\sim 600 \mathrm{Ma})$ for the carbonate sedimentation of the Una and Bambul Groups, including the Vazante Formation.

In Morro Agudo, the sulfide mineralization is composed of sphalerite, galena and minor pyrite, associated with calcite, microquartz (length slow), megaquartz and barite. Massive or disseminated, the individual ore deposits are distributed along a fault zone and subdivided into 4 main orebodies by the mine geologists of the CMM (Romagna and Costa, 1988) (Fig. 8). They are:

M Orebody: Coarse grained, gash-veins in dolarenites, discontinuous. Remobilized.

N Orebody: Fine grained, stratiform mineralization in dolarenitic beds.
JKL Orebody: Massive, fine to coarse grained, cementing oolitic dolostone beds.

GHI Orebody: Coarse grained, cementing brecciated structures.

Petrographic studies of the stratiform mineralization revealed the presence of nodular mineralization associated with microcrystalline, fibrous and length-slow quartz, which is an indication of the presence of a previous evaporitic facies controlling the stratiform mineralization.

Lead isotope data of galenas carried out by Iyer (1984) and Iyer et al. (1992) in the Vazante-M.Agudo and neighbouring regions, showed secondary isochron line that cut the model evolution curve at $1800 \mathrm{Ma}$ and $650 \mathrm{Ma}$. This was interpreted as being due to the derivation of major portion of lead from the basement rocks of Transamazonian age. A zoning in the isotopic composition of the Morro Agudo area was also observed: The lead becomes progressively radiogenic away from the fault zone. This could be an indication that the normal fault at Morro Agudo was a feeder zone. The secondary isochron observed is 


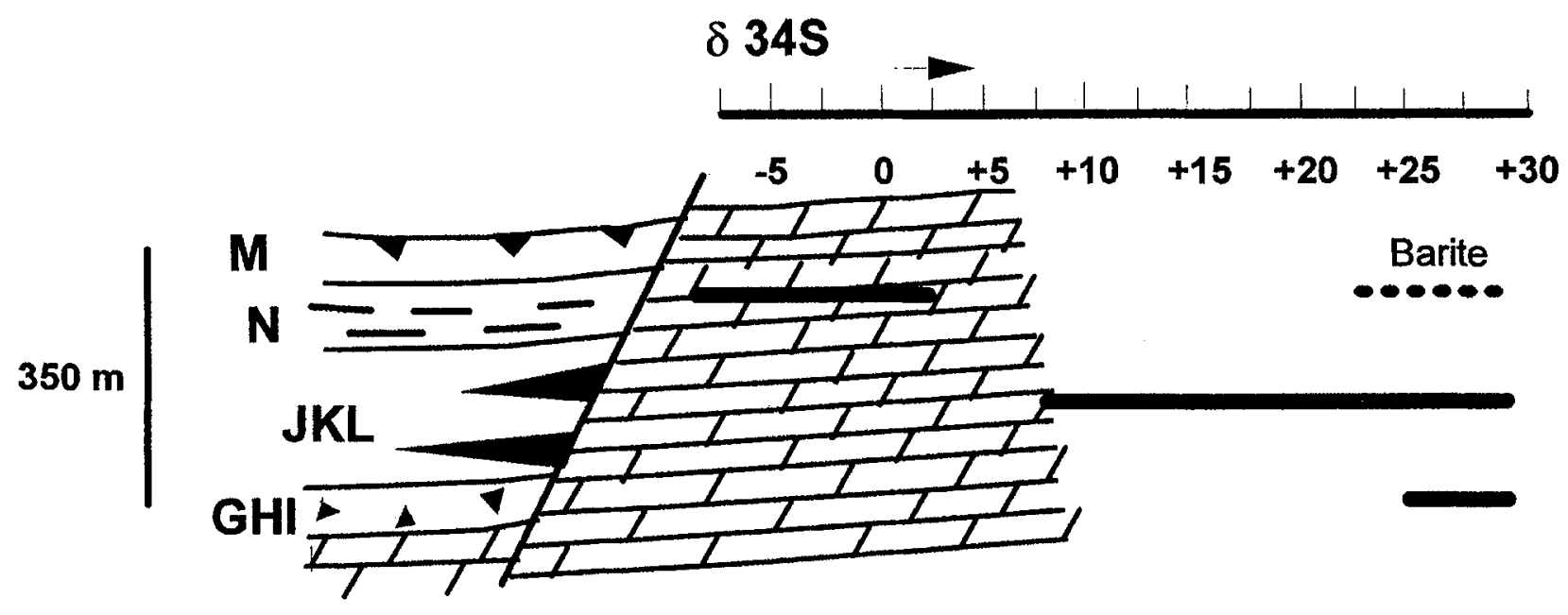

\section{Gash-veins (remobilized) JKL Stratabound, massive N Stratiform + dissemin. $\quad$ GHI Breccia}

Fig. 8. Schematic representation of the distribution of the main orebodies in the Morro Agudo mine related to the fault zone, according to Romagna and Costa (1988). The sulfur isotope variation of sulfides and barite in the orebodies is also indicated.

probably the result of the mixing of lead from the basement and from the sediments. Such a mixing (anomalous lead) could yield model ages either younger or older than the age of the sediments (Gulson, 1986). The lead isotope investigations on the carbonate rocks and acid leaches performed by Babinski (1993), have revealed the presence of different types of lead and isochron ages in some areas suggesting the resetting of the lead isotope system during the Brazilian orogeny. A comparison of the lead isotope pattern of the carbonates and the ore samples support the mixing pattern. Recent $\mathrm{Pb}$ isotopic study of the Proterozoic Bell Purcell Basin by Beaudoin (1997) revealed a linear array of the data points for the sulfides of the Sullivan deposit, in Canada. This was interpreted as resulting from the mixing of the upper crustal and/or orogen $\mathrm{Pb}$ with that of basement rocks. The study also revealed that the sulfides were altered up to $108 \mathrm{Ma}$ after the deposition by hydrothermal fluids that leached the Sullivan array and deposited the more radiogenic lead of the Sullivan alteration. Thus further detailed sampling and isotopic analyses in the VazanteMorro Agudo area is warranted.

The detailed sulfur isotope studies recently carried out by the present authors on 34 samples of sulfides, confirm the hypothesis of the feeder zone associated to the fault system at Morro Agudo mine: There is a clear trend from high positive values in the lowermost, breccia-type GHI orebody (ave. $\delta^{34} \mathrm{~S}=+26.1 \% \mathrm{CDT}, \mathrm{n}=2$ ) to less positive values at the oolitic, stratabound JKL (ave. $+18.5 \%, \mathrm{n}=12$ ) and moderate negative values in the uppermost, stratiform $\mathrm{N}$ orebody (ave. $-3.0 \%, \mathrm{n}=11$ ) (Fig. 8). Temperatures obtained from cogenetic sphalerite-galena pairs, using Ohmoto and Rye (1979) equation show a remarkable variation ranging from 257 degrees celsius in the GHI orebody $\left(\Delta^{34} S\right.$ sph-gal $\left.=2.6\right), 197,134$ and 112 in the JKL $\left(\Delta^{34} S\right.$ sph-gal $=3.3,4.4$ and 4.9 ) and 112 and 45 degrees in the $\mathrm{N}$ orebody $\left(\Delta^{34} \mathrm{~S}\right.$ sph-gal $=4.9$ and 7.2). The M orebody indicates very low temperatures, plotting outside the temperature curves, confirming the possibility of a origin by late remobilization.

Six barite samples analysed for their sulfur isotopic composition, indicated a narrow range of values, between 23 and $28.5 \%$ CDT (mean of $26 \%$ ). These values are compatible to those obtained by Iyer et al. (1992) from the same area. They could reflect original late Proterozoic seawater sulfate values, according to Claypool et al. (1980) and Strauss (1993).

The above data suggest that metal-rich solutions migrated from the basement through the fault zone during extensional episodes of the basin and reacted with reduced sea water sulfur. The replacement nature of most of the mineralization suggest that the main phase of ore formation may have occurred during the early diagenetic stages of the carbonate sedimentation.

Irecêe

$\mathrm{Zn}-\mathrm{Pb}-\mathrm{Ag}$ sulfide mineralization in the Irecê Basin was discovered by Riofinex do Brasil in 1979, by drilling near a gossan occurrence in the central part of the Irecê Basin, in Bahia state. This is a small, apparently isolated basin within the São Francisco Craton (Fig. 9), filled with glaciogenic 


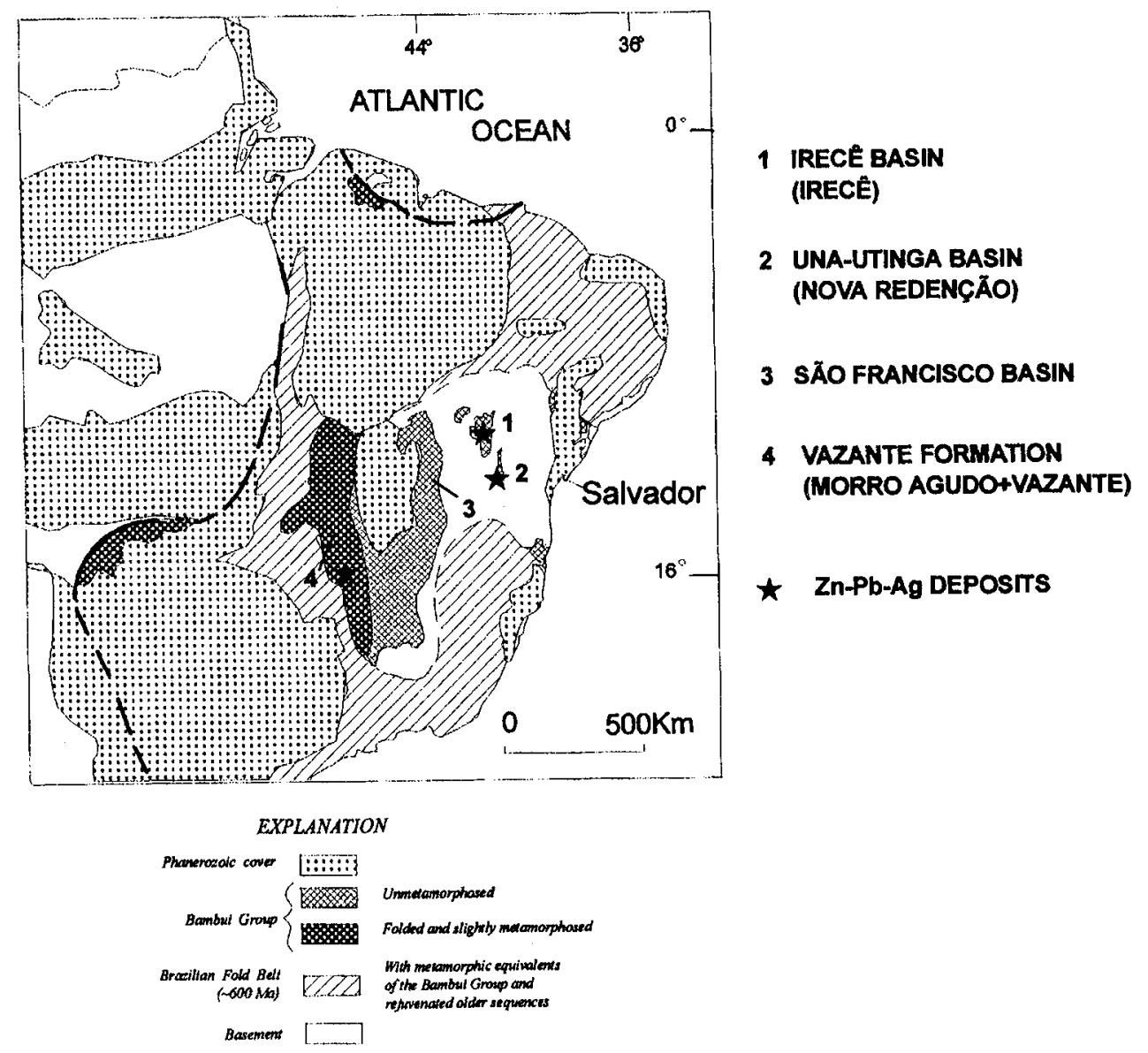

Fig. 9. General geology of eastern Brazil, showing the São Francisco Craton, the Neoproterozoic basins (including the Vazante Formation) and the $\mathrm{Pb}-\mathrm{Zn}$ deposits sutudied.

sediments (Bebedouro Formation) and carbonate packages (Salitre Formation) of the Neoproterozoic Una Group, correlatable with the better known Bambul Group (Misi et al., 1997). In 1989 Companhia Baiana de Pesquisa Mineral (CBPM) defined a small 1.5 million tonnes of reserves averaging $8 \% \mathrm{~Pb}+\mathrm{Zn}$ and $120 \mathrm{~g} / \mathrm{t} \mathrm{Ag}$ (Monteiro, 1989). In 1985, Companhia de Pesquisa de Recursos Minerais (CPRM) discovered in the area of the gossans, economic stromatolitic phosphate concentrations in the same geological setting of the metallic mineralization, but at a slightly higher stratigraphic position. The phosphate concentration is associated with columnar stromatolitic structures of nearly $15 \mathrm{~cm}$ long, and was formed during the earlier stages of the diagenetic evolution. Its origin appear to be organic (Misi and Kyle,1994).

Stratabound sulfide mineralization and phosphate concentration occur within a $50 \mathrm{~m}$ thick tidal flat sequence of the Salitre Formation. This formation comprises at least $1.2 \mathrm{~km}$ of predominantly carbonates, lying unconformably over the glaciogenic sediments (diamictites) of the Bebedouro Formation and over the Mesoproterozoic siliciclastic metasediments of the Chapada Diamantina Group. Misi (1978) and Misi and Kyle (1994), identified two transgressive-regressive cycles in the carbonate sedimentation. Sulfide and phosphate mineralizations are positioned in the top of a shallowing upward sequence, corresponding to the first cycle (Fig. 10). In the Irecê Basin several other sulfide and phosphate occurrences are widespread, in the same stratigraphic position.

Stratabound massive or disseminated $\mathrm{Zn}-\mathrm{Pb}-\mathrm{Ag}$ sulfide concentrations are associated with dolostone showing shallow-water sedimentary structures, such as tepee structures, length-slow quartz nodules, and pseudomorphs after evaporitic sulfates. Sulfide minerals are pyrite, sphalerite, galena, marcasite, jordanite, tetrahedrite and covellite, associated with dolomite, calcite, microquartz (fibrous, length-slow), barite, baroque dolomite, gypsum and megaquartz. They occur as fine-grained disseminations, laminae, lenses, irregular masses, nodular aggregates, and breccia and fracture filling (Kyle and Misi, 1997). Replacement textures between sulfide minerals are 


\begin{tabular}{|c|c|c|c|}
\hline \multirow[b]{2}{*}{$\Gamma^{0 \mathrm{~m}}$} & UNITS & & DESCRIPTION \\
\hline & $\begin{array}{l}\text { A1 } \\
\text { A }\end{array}$ & CYCLE & $\begin{array}{l}\text { Black, } \\
\text { organic-rich } \\
\text { limestone } \\
\text { Pelites,marls }\end{array}$ \\
\hline \multirow[t]{2}{*}{-150} & B1. & $\left.\right|_{\text {CYCLE }} ^{\substack{\text { zn,pob } \\
p_{2200}}}$ & $\begin{array}{l}\text { Chert dolomite } \\
\text { Laminated } \\
\text { dolomitic } \\
\text { limestone }\end{array}$ \\
\hline & ...8....... & & $\begin{array}{l}\text { Red dolomite } \\
\text { Diamictites }\end{array}$ \\
\hline
\end{tabular}

Fig. 10. Stratigrapliy of the Una Group, Irecê Basin, and the two transgressive-regressive cycles, according to Misi and Silva (1996)._Sulfide and phosphate mineralizations are associated with shallow water carbonates, mainly dolomites, of the first cycle.

common. Pyrite crystal aggregates commonly show bladed forms, pseudomorphs after evaporites (gypsum).

Sulfur isotope analysis of sulfides and sulfates show a relatively uniform heavy $\delta{ }^{34} S$ values. The range for the sulfates (barite and gypsum)_is from +25 to $+31 \%$ CDT (mean of $+27.7, \mathrm{n}=9$ ). The sulfides, corresponding to a variety of textural forms, have a $\delta^{34} \mathrm{~S}$ range of +19 to $+23 \%$ (mean of $+21.3, n=19$ ). The $\delta^{34} S$ values obtained for the Irecê sulfates, probably represent original sea-water sulfate values (Strauss, 1993). As pointed out by Kyle and Misi (1997), "the consistently heavy $\delta^{34} S$ values of the Irecê sulfides are likely the result of thermochemical reduction of a limited evaporitic sulfate source by organic matter, that is abundant in the Salitre carbonates". Limited fluid inclusion data from sphalerite, suggest a temperature of formation in the range of 140 to $200^{\circ} \mathrm{C}$, and salinities ranging from 3 to $12 \mathrm{wt} \%$ for the formation waters. The association of Três Irmãs sulfides with calcite interpreted to be of meteoric origin (Misi and Kyle, 1994), as well as the range of fluid inclusion compositions and temperatures, suggests that the mineralization may have occurred within a mixing zone of metal-bearing basinal brines with meteoric water.

Summarizing, the petrographic, isotopic and fluid inclusion data indicate that sulfide mineralization occurred within a mixing zone of metal-bearing, relatively high temperature basinal brines with meteoric waters. Metal bearing mineralizing fluids scavenged sulfur from preexisting sulfides or the sulfides were formed from direct reduction of evaporitic sulfate minerals. Deep fluid circulation may have been promoted by reactivation of old basement faults during the Irecê Basin formation and evolution. However, the presence of such possible aligned structures directly associated with the mineralization, as observed in the Morro Agudo and Nova Redenção deposits, is not evident in the Irecê Basin.

\section{Nova Redenção}

Exploration work by CPRM in the Neoproterozoic UnaUtinga Basin (Fig. 9) between 1987 and 1990, indicated the presence of several lead-zinc and barite showings, as well as impressive soil and stream sediment geochemical anomalies and gossans. CPRM also discovered a small $\mathrm{Pb}$ $\mathrm{Zn}(\mathrm{Ag})$ deposit in the Nova Redenção area (2.5 million tonnes, $6.3 \% \mathrm{~Pb}, 0.5 \% \mathrm{Zn}$ and $33 \mathrm{ppm} \mathrm{Ag}$ ), located in the southern part of the basin. Further detailed mapping and drilling by Moraes Filho and Leal (1990) in the Nova Redenção area showed the intimate relationship of the deposits with aligned structures oriented approximately NW-SE. In 1995, the Research Group on Metallogenesis of the University of Bahia initiated a research program in Nova Redenção, with a view to develop a metallogenic model consistent with the other lead-zinc mineralization of the Neoproterozoic basins of the São Francisco Craton (Gomes, 1998). The preliminary results of this research under progress will be briefly discussed here.

The Una-Utinga Basin is filled with predominantly carbonate sequences with the same stratigraphic organization as for the Irecê Basin. Diamictites of the glaciogenic Bebedouro Formation are unconformably succeeded by limestones and dolomitic limestones, with the same stratigraphic succession of the Salitre Formation, in the Irecê Basin. $\mathrm{Pb}-\mathrm{Zn}(\mathrm{Ag})$ mineralization is in direct association with silicified oolitic dolarenites and dolomitic breccia, that correspond to the uppermost section of a shallowing upward sequence. Although intensely silicified, these dolomitic beds preserve sedimentary structures indicative of shallow water evaporative formation, such as nodules of microquartz (fibrous, length slow), quartz pseudomorph of sulfates (gypsum), tepee structures and laminar stromatolites.

Sulfide minerals are mainly stratabound galena, sphalerite, pyrite, cerussite and anglesite, associated with microquartz, megaquartz, hematite and barite. They occur as massive lenses, disseminations in the dolarenites, cementing the matrix of oolitic structures and brecciated dolostones, forming nodules and remobilized veins. The close association of all mineralization with fracture zones aligned N45W is truly remarkable. They can be followed for more than $10 \mathrm{~km}$ in the Nova Redenção area and are characterized by the presence of brecciated strucutures and shear zones (Fig. 11).

Lead isotope data of seven galena samples from the Nova Redenção deposits show highly radiogenic compositions and plot above the upper curve in the lead evolution diagram. The calculated model age values are in the range 


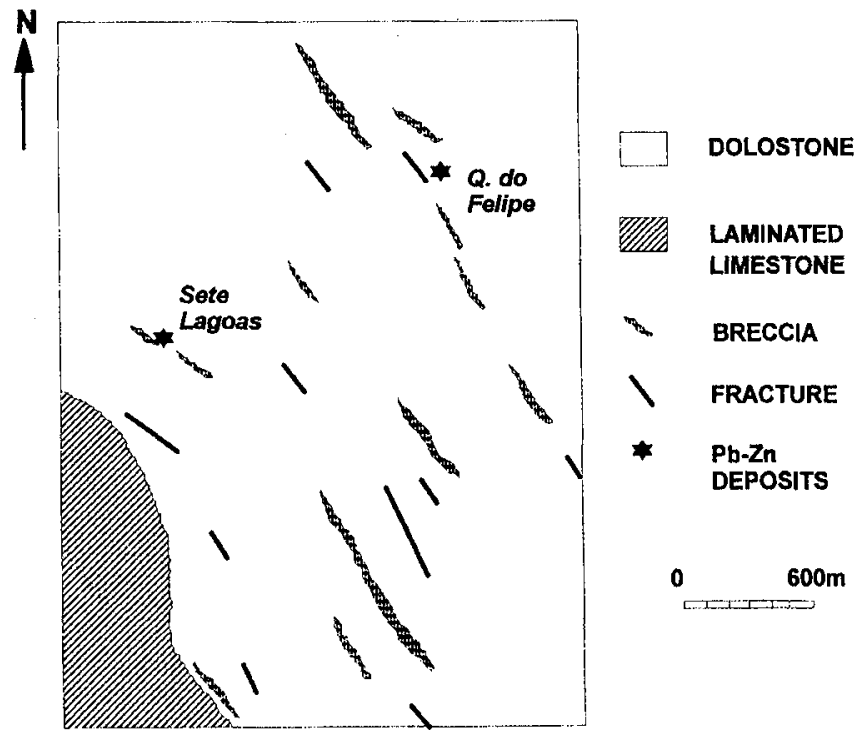

Fig. 11. Simplified geological map of Nova Redenção area, with the two main $\mathrm{Pb}-\mathrm{Zn}$ deposits closely associated with NW-SE fractures and aligned breccia zones. Modified after Moraes Filho and Leal (1990).

of 400 to $600 \mathrm{Ma}$. The disposition of the data points imply the derivation of the lead from multiple sources, mainly from the sediments. The predominant radiogenic lead observed in Nova Redenção suggest the derivation from accessory minerals in the sediments. The relatively high temperatures obtained from the fluid inclusions studies (discussed in a latter section) may also suggest a short time interaction of fluids with the sediments. Further the fluids must have carried some $U$ and $T h$ in close association with the lead, probably with the lead or as inclusions. The model age values, though not precise, are approximately concordant with the geological ages. The relatively more radiogenic lead samples may give younger ages. Similar radiogenic leads were found in the Sullivan mine, Canada (Beaudoin, 1997).

Sulfur isotope analyses reveal very high $\delta^{34} S$ values for barite from the Nova Redenção deposit, ranging from +33.6 to $+40.9 \%$ CDT $(n=4)$, compatible with those expected for the sea-water composition during the terminal Proterozoic (Strauss, 1993). Galena, sphalerite and pyrite show a wider variation, between -0.1 and $+18.6 \%$ CDT (mean of +13.8 , $\mathrm{n}=19$ ). Although this large range of variation could suggest a bacteriogenic reduction of sea-water sulfates, the temperatures obtained by using fractionation factors of sulfur isotopes from two samples of coexisting galenasphalerite pairs (using Ohmoto and Rye, 1979 equation), do not allow this interpretation. The calculated temperatures of $154^{\circ} \mathrm{C}\left(\Delta^{34}\right.$ Ssph-gal $\left.=4\right)$ and $197^{\circ} \mathrm{C}\left(\Delta^{34} \mathrm{~S}\right.$ sph-gal $\left.=3.3\right)$ are too high for bacterial activity.
Fluid inclusion thermometry in sphalerite from the same samples confirm these values. Homogenization temperatures of 134 primary two-phase inclusions, reveal relatively high temperatures between 150 and $220^{\circ} \mathrm{C}$ (mode of $\left.185^{\circ} \mathrm{C}\right)$. For all measured inclusions $(\mathrm{n}=137)$, temperatures of first observed melting range from $-5^{\circ}$ to $60^{\circ} \mathrm{C}$. About $70 \%$ of the inclusions showed only one phase transition, with the majority (about $72 \%$ ) displaying these temperatures above $-21.2^{\circ} \mathrm{C}$, suggesting that composition of the fluids can be modelled in the system $\mathrm{H}_{2} \mathrm{O}-\mathrm{NaCl}$. Around $30 \%$ of the inclusions showed two phase transitions with half of the data below $-21.2^{\circ} \mathrm{C}$, suggesting the presence of calcium, potassium, and/or magnesium in addition to sodium and chlorine. The last solid melted, observed in the inclusions that showed last melting point above the eutectic of the $\mathrm{H}_{2} \mathrm{O}-\mathrm{NaCl}$ system, could not be identified due to the small size of the inclusions (usually less than $10-\mu \mathrm{m}$ ). It could be either ice or hydrohalite $\left(\mathrm{NaCl} \cdot 2 \mathrm{H}_{2} \mathrm{O}\right)$. The salinities calculated from the last melting of ice and hydrohalite showed modes of $22.8 w t \% \mathrm{NaCl}$ and $23.8 \mathrm{wt} \% \mathrm{NaCl}$ respectively. The error of about $1 \mathrm{wt} \% \mathrm{NaCl}$ is probably due to the nonidentification of this last solid to melt and has minor significance in the total salinity determinations. These highly saline fluids could be the result of incorporation of basinal brines or infiltration of evaporative surface waters (Leach and Sangster, 1993). The presence of preserved sedimentary structures such as nodules of microquartz (fibrous, length slow) and quartz pseudomorphs of sulfates (gypsum), indicative of shallow water evaporative formation at the depositional site, suggest that the high salinity of these fluids could be attributed to the solution of evaporites, probably by a metal-rich moderate saline brine.

The close association of the mineralization with aligned fractures and the stratigraphic control in close association with evaporative facies argue in favor of a model for Nova Redenção similar to that proposed for Morro Agudo and for Irecê. Fluid circulation of metal-bearing fluids promoted by reactivated basement structures and deposition in evaporative facies by direct reduction of sulfate minerals, during the early diagenetic evolution of the carbonates.

\section{Late Proterozoic to Early Paleozoic \\ Santa Maria}

The Santa Maria $\mathrm{Pb}-\mathrm{Zn}(\mathrm{Ag})$ deposit has been studied by Companhia Brasileira do Cobre (CBC). Badi (1983) performed a regional study of the Camaquã District, where are located the mines of Camaquã (copper) and Santa Maria (Pb-Zn). More recently, Remus et al. (1997) carried out $\mathrm{Pb}$ and $\mathrm{S}$ isotope investigations in the deposit, in an attempt to constrain the timing of the mineralization and the source of metals and sulfur.

Mineralization in Santa Maria is composed of massive galena (veins and disseminations), with pyrite and minor 
chalcopyrite and bornite. The gangue minerals are quartz, carbonates, plagioclase, microcline, biotite, tourmaline and clay minerals. The mineralization is formed in the matrix of arkosic sandstones and conglomerates of the Arroio dos Nobres Formation (Bom Jardim Group, Camaquã Basin), that was interpreted as deposited by a deltaic system (Badi, 1983). There are andesitic volcanic flows intercalated in the basal siliciclastic member (Hilário Member) (Fig. 12). Two fault systems oriented NE and NW control the mineralization, especially in the copper mineralization at the Camaquã mines, situated about $5 \mathrm{Km}$ to the NE of Santa Maria. The Bom Jardim Group was deposited in graben structures over the Archean-Paleoproterozoic basement.

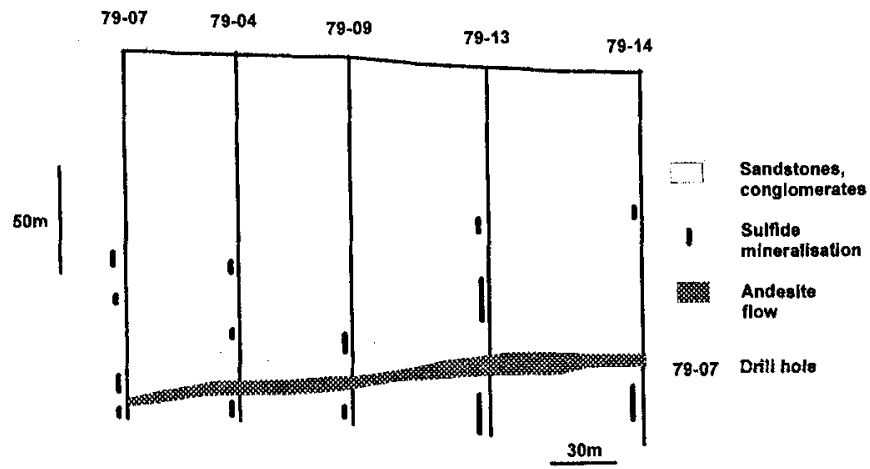

Fig. 12. Cross section of the Santa Maria deposit, simplified after Badi (1983).

The $\mathrm{Pb}$ isotope data obtained by Remus et al. (1997) for the sulfides from both the deposits (Camaquã and Santa Maria), along with the data for unaltered sedimentary rocks of the Bom Jesus Group performed by the same author, plot in a linear array. This array is subparallel to the $\mathrm{Pb}-\mathrm{Pb}$ isochron line (596 Ma) of the Lavras granite and Hilario volcanic formation, suggesting an age of the mineralization coeval with the formation of these rocks. The significantly more radiogenic composition of some of the sulfides imply the source of lead to be the sediments. The lead was probably derived by a hydrothermal fluid during its ascent through the sedimentary pile. The sulfides carried U-bearing phases in close association or as inclusions. A simple calculation would indicate $\mathrm{U}$ concentrations of 0.03 to $0.04 \%$ of $\mathrm{U}$ in some of the sulfides.

The sulfur isotope data for sulfides of Santa Maria Deposit $(-2.6 \%$ to $+1.1 \%$ CDT $)$ obtained by Remus et al. (1997) are in the same range as the values obtained by us for five samples of galena and sphalerite $(-3.6 \%$ to $+4.1 \%$ CDT). These data are indicative of a deep seated (magmatic?) source of sulfur in the sulfides. Barite samples from the distal parts of the sulfide veins yielded $\delta^{34} S$ values of +10.3 to $+14.1 \%$, indicating mixing between the marine water and magmatic sources (Remus et al., 1997). Geothermometric data based on the sulfide isotope fractionation between coexisting galena and sphalerite pairs yielded temperatures in the range of 280 to $310^{\circ} \mathrm{C}$ (Remus et al., 1997).

\section{Discussion}

The $\mathrm{Pb}-\mathrm{Zn}$ sediment-hosted deposits studied here do not appear to possess significant metal reserves, as commonly observed in other mineralized Proterozoic basins around the world. However, they share some important characteristics with the sediment-hosted massive sulfide class of ore deposits, as described by Large (1983), in which most of the known world-class $\mathrm{Pb}-\mathrm{Zn}$ deposits are included. Nevertheless, the deposits studied differ from the classical SEDEX model of sulfide deposits in some respects: Except for the Santa Maria mineralization, all the deposits are associated with carbonates, instead of predominantly siliciclastic rocks, and there is an apparent absence of contemporaneous igneous activity during the basin sedimentation. In addition, the syn-diagenetic nature of most important mineralization in these deposits is in direct contrast of the syngenetic model applied for most of the classical SEDEX deposits.

The Brazilian deposits studied here have also some geological and geochemical characteristics that could indicate a common metallogenic evolution, related to the tectonic and diagenetic evolution of the host basins. The remarkable stratigraphic control, the association with contemporaneous normal faults, the relative high temperatures of formation and the massive nature of the mineralization as described in most deposits, all argue in favour of an origin related to a focused hydrothermal release of metal-bearing fluids along fractures and fault zones, during the basin evolution and before the deformation stages. This process was apparently active during important extensive phases of the basins, irrespective of their ages.

In this respect, the Archean-Paleoproterozoic Boquira deposit can be certainly considered a rarity. This is attributed to the fact that the conditions favourable for deposition of sediment-hosted sulfides, especially the ones containing lead, emerged later in the evolutionary history of the earth. As pointed out by Gale (1983), "Archean crustal conditions may not have been conducive to the formation or preservation of thick sequences of sediments in major sedimentary basins". This has led to confine exploration in sedimentary basins to younger terranes than the Archean. However, if not for scientific arguments, the economic exploitation of Boquira, that operated for more than forty years, warrants the need to amplify the exploration horizons to the Archean terranes.

On the other hand, there is an apparent paradox concerning the Neoproterozoic deposits, such as Morro 
Agudo, Irecê and Nova Redenção: If the São Francisco and Irecê Basins (Bambuí and Una Groups), that host these mineral deposits are foreland basins, as indicated by their 0.60 to $0.65 \mathrm{Ga}$ ages, coeval with the compressive phase of the Brasiliano/Pan African orogeny $(0.75$ to $0.55 \mathrm{Ga}$, Pedrosa Soares et al., 1992) how can we argue in favour of an extensional event related to the origin of the mineralization? Regardless the unquestionable association of the Morro Agudo and Nova Redenção deposits with aligned structures as previously demonstrated, must lead us to consider the Brasiliano/Pan African orogeny was a long epoch event. The existence of extensional events during the long compressive history of the Brasilano orogeny is probably related to the reactivation of old basement structures. In fact, the cyclic organization of the Bambui and Una carbonate packages, with at least two trangressive-regressive cycles, and the clear association of the mineralization with the top of a shallowing upward sequence (1st cycle), endorses this
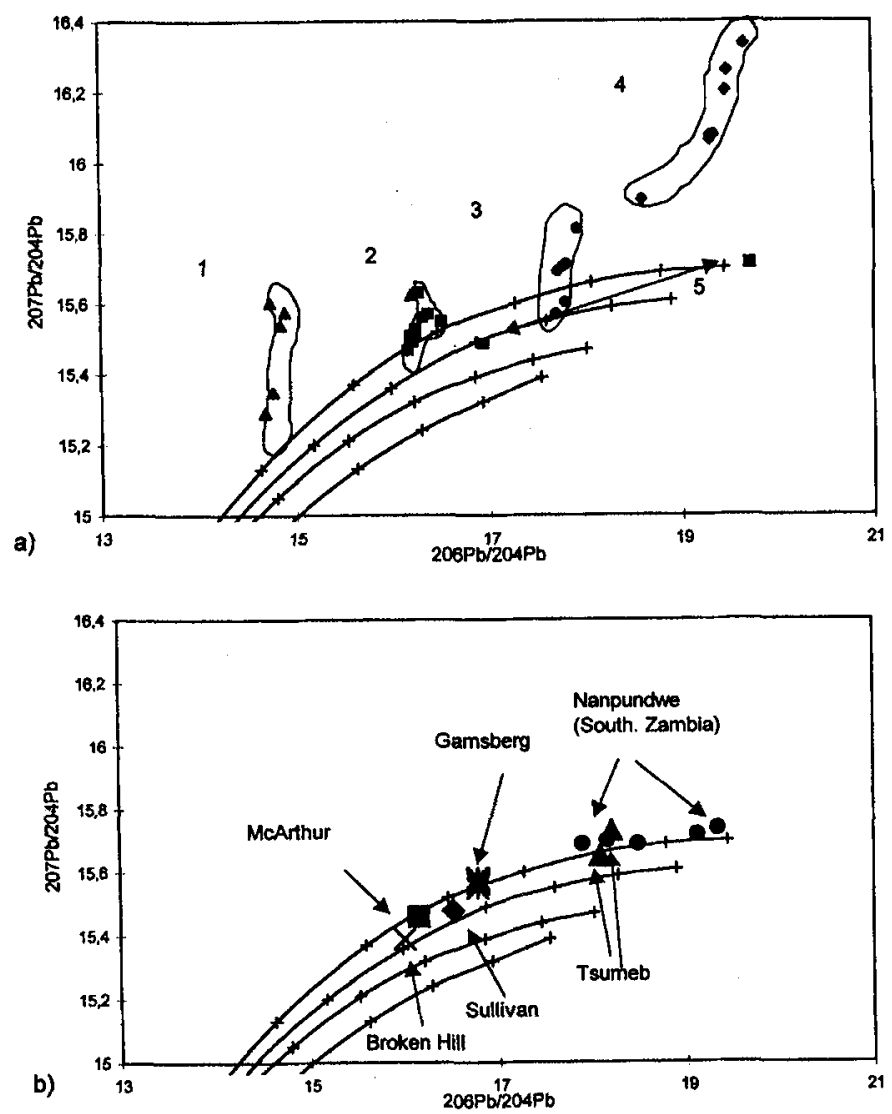

Fig. 13. a) Lead isotope composition of galena from the sedimenthosted deposits studied. Evolution curves according to the plumbotectonic model of Zartman and Doe (1981), upper curve corresponding to the evolution in the upper crust (UC), followed by the mantle (MN), orogen (OR) and lower crust (LC) evolution curves. 1-Boquira 2-Canoas 3-Morro Agudo 4 - Nova Redenção 5 - Santa Maria. b) Lead isotope composition of some world-class Proterozoic sediment-hosted sulfide deposits. proposition. The common geological and mineralogical characteristics are reflected in the isotopic data. The lead isotope data of five deposits are shown in the lead evolution curve of Zartman and Doe (1981) (Fig. 13a). The model age values calculated are approximately concordant with the respective geological ages. The data points for all the deposits plot close to or above the evolution curve for the upper crust suggesting the derivation of the metal from upper crustal sources. These points, when plotted in the thorogenic diagram of the same authors, agree with the derivation of lead from upper crustal sources. These sources could be basement rocks and the sediments themselves. Thus, our lead isotope data conform to the general trend for the sediment-hosted sulfide deposits, as demonstrated by Large (1983), in which the stratabound sulfides are generally homogeneous. The Fig. 13b shows the overlapping of our data with those of some world-class $\mathrm{Pb}-\mathrm{Zn}$ deposits, probably indicating similar conditions of formation. The lead isotopic data of the Brazilian deposits show linear trends similar to those observed for the Sullivan deposit, in Canada and other Sedex deposits (Beaudoin, 1997). Further isotope analyses (in progress) should define trends for the individual deposits. Such trends should help not only to better define mineralization epochs, but also will be valuable for exploration program.

The sulfur isotopic composition of the sulfides and sulfates from the different Proterozoic sediment-hosted deposits are shown in Fig. 14. Excepting for the Santa Maria mineralization, the isotopic data for all the deposits indicate a predominant sea water source for the sulfur. In the Santa Maria deposit the source of the sulfur appears to be volcanic, with little contribution from the sediments. In the other deposits, geologic, petrographic, thermometric and isotopic data points to the possibility of thermochemical reduction of sea water sulfates.

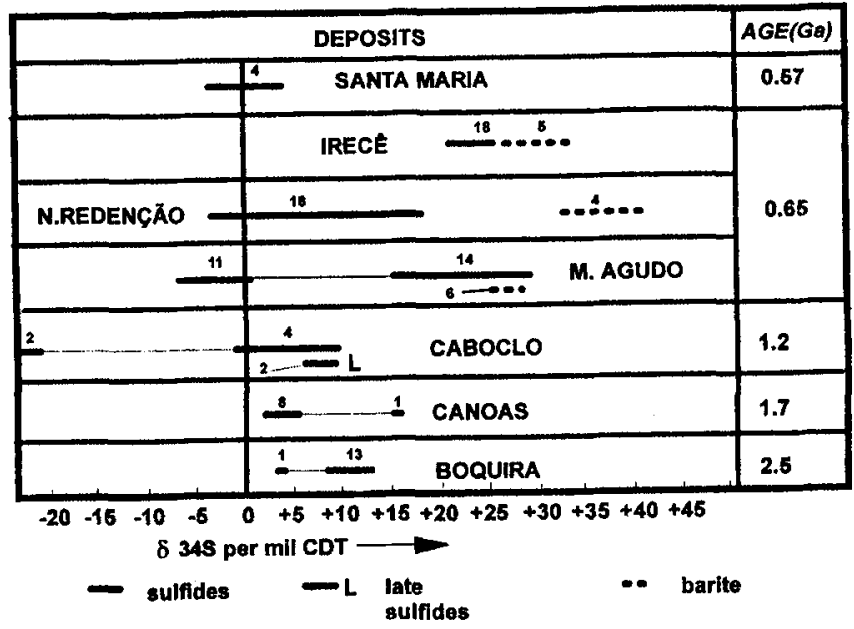

Fig. 14. Sulfur isotope variation of sulfides and sulfates from the sediment-hosted deposits studied. Figures above the lines indicate the number of determinations for the indicated range. 


\section{Conclusions}

This study discusses the geological, petrographic and isotopic characteristics of different sediment-hosted $\mathrm{Pb}-\mathrm{Zn}$ deposits of Brazil, ranging from $2.5 \mathrm{Ga}$ to $0.6 \mathrm{Ga}$. The remarkable common characteristics of these deposits indicate similar origin over a broad time range. The timing of formation coincides with important extensional episodes in the continent suggesting the repetitive nature of the oreforming processes.

The $\mathrm{Pb}$ isotope data support a model involving the action of hydrothermal fluids carrying metals from the basement. The $S$ isotope data point to a sea water origin of the sulfur in six of the deposits studied and probably derived from the intermediate volcanic flows intercalated in the host sediments, in the Santa Maria deposit. In this deposit, the source of sulfur appears to be magmatic with little contribution from the sedimentary sources. In some cases, mixing fluids may be involved. The association of the mineralization with linear structures (normal faults and/ or fractures), as observed in most deposits, is an indication of the kind of the main pathways available for the fluids. Deposition took place mainly by thermochemical reduction of sulfates and subsequent replacement of evaporative sulfate-rich carbonates during the early diagenetic stages, as demonstrated for the Neoproterozoic deposits.

The study emphasizes that the mineral deposits have to be viewed in their geotectonic context. Further, the existing metallogenic models have to be revised by using integrated geological, tectonic, geochemical and isotopic information. This should launch the exploration strategy in a more scientific basis.

\section{Acknowledgements}

We are grateful to Dr. R. Krouse, for making available the facilities of the Stable Isotope Laboratory at the University of Calgary. We are also grateful to Dr. C. B. Dissanayake and anonymous referees for their suggestions on an earlier version of the manuscript. Nenita Lozano is thanked for the sulfur and oxygen isotope analysis of sulfides and sulfates from most of the deposits studied. We are also grateful to Ján Veizer and Gilles St Jean, from the University of Ottawa, Canada, and to W.C.Shanks III and Tim Johnson, from the U.S.Geological Survey at Reston, Virginia, who made possible the analysis of stable isotopes from the Caboclo and Irecê deposits, respectively. CNPq, the National Research Council of Brazil, CBPM, CPRM and CMM provided partially the funds to make possible this research. We are especially grateful to $\mathrm{M}$. Marinho, J.C.Gonçalves and T.F.Oliveira, from the companies cited. This paper is a contribution to the IGCP UNESCO Project $\mathrm{N}^{\circ} 342$, "Age and Isotopes of South American Ores".

\section{References}

Babinski, M. (1993) Idades isocrônicas $\mathrm{Pb} / \mathrm{Pb}$ e geoquímica isotópica de $\mathrm{Pb}$ das rochas carbonáticas do Grupo Bambuí na porção sul de Bacia do São Francisco. Unpublished Ph.D thesis, Universidade de São Paulo, Brazil. 133 p.

Babinski, M., Van Schmus, W. R., Chemale, F. JR. and Kawashita, K. (1993) Evolução geológica da parte sul da bacia do São Francisco baseada na geoquímica isotópica de $\mathrm{Pb}$ em rochas carbonáticas: Proc.: II Simpósio sobre o Craton do São Francisco-Evolução, Tectônica e Metalogenética do Craton do São Francisco. Sociedade Brasileira de Geologia/ Superintendência de Geologia e Recursos Minerais (SBG/ SGM), Salvador, Brazil, pp. 182-185.

Badi, W. S. R. (1983) Mineralizações de chumbo e zinco em arenitos do distrito de Camaquã, Rio Grande do Sul. Unpublished Master's Dissertation, Post-Graduate Course in Geology, Universidade Federal do Rio Grande do Sul (UFRGS), Brazil, 137 p.

Beaudoin, G. (1997) Proterozoic Pb isotope evolution in the BeltPurcell Basin: Constraints from syngenetic and epigenetic sulfide deposits. Econ. Geol., v.92, pp. 343-350.

Bez, L.(1979) Mineralogy and geochemistry of the Morro Agudo zinc-lead deposit, Brazil. Unpublished MA dissertation, University of Missouri, USA, $74 \mathrm{p}$.

Bortnikov, N.S., Dobrovol'skaya, M.G., Genkin, A.D., Naumov, V.B. and Shapenkov, V.V. (1995) Sphalerite-galena geothermometres: Distribution of cadmium, manganese, and the fractionation of sulfur isotopes. Econ. Geol., v.90, pp. 155-180.

Carvalho, I.G. (1982) Geology of the Pb - Zn Boquira District, Bahia, Brazil. Proc.: Cong. Latino Americano de Geologia, 4, Buenos Aires, Argentina, v.2, pp.221-228.

Carvalho, I.G. (1985) Host rock geochemistry and its contribution to the genetic interpretation of the Boquira $\mathrm{Pb}$ - Zn deposit, Bahia State, Brazil. Proc.: Cong. Latino Americano de Geologia, 7, Belém (Brazil), v.5, pp. 216-229.

Carvalho, I.G., Zantop, H. and Torquato, J.F.R. (1982) Geologic setting and genetic interpretation of the Boquira $\mathrm{Pb}-\mathrm{Zn}$ deposits, Bahia, Brazil . Rev. Bras. Geociências, v.12, pp.414435.

Carvalho, I.G., Iyer, S.S., Tassinari, C.C.G. and Misi, A. (1997) Lead and sulfur isotope investigations of the Boquira sediment-hosted sulfide deposit, Brazil. Int. Geology Review, v.39 (2), pp. 97-1.06.

Cassedanne, J. (1966) Métallogenie du plomb et du zinc dans l' État de Bahia. Anais da Academia Brasileira de Ciências, v. 38(3/4), pp. 465-474.

Claypool, G.H., Holser, W.T., Kaplan, I.R., Sakai, H. and Zak, I. (1980) The age curves of sulfur and oxygen isotopes in marine sulfate and their mutual interpretation: Chemical Geology, v. 28 pp. 199-260.

Conceição Filho, V.M. and Silva, R.W. (1984) Projeto Borda Norte da Chapada Diamantina, Fase II, $2^{\text {n }}$ etapa Secretaria das Minas e Energia/Companhia Baiana de Pesquisa Mineral, Salvador, 35 p. (Unpublished report).

Conceição Filho, V.M., Monteiro, M.D, Carvalho, M.P., Souza, W.S.T. (1993) Geologia e potencialidade para mineralizações de cobre, chumbo, zinco e prata da borda norte da Chapada Diamantina, Bahia. Companhia Baiana de Pesquisa Mineral, Open File Report n 1, Salvador, 24 p. 
Conceição Filho, V.M., Silva, R.W.S. and Lima, O.A.L. (1986) Controle estratigráfico das mineralizações de $\mathrm{Cu}, \mathrm{Pb}$ e Ag nos metassedimentos da borda norte da Chapada Diamantina, Bahia. Proc.: Congresso Brasileiro de Geologia, 34, Soc. Bras. Geologia, Goiânia, v. 5, pp. 2105-2121.

Corrêa Gomes, L.C., Tanner de Oliveira, Motta, A.C. and Cruz, M.J.M. (1996) Províncias dos diques máficos do Estado da Bahia. Mapa, estágio atual do conhecimento e evolução temporal. Convênio Secretaria das Minas e Energia/ Universidade Federal da Bahia/Programa de Pesquisa e Pós-Graduação em Geofísica e Geologia/Fundação de Amparo à Pesquisa e Extensão (SME/UFBA/PPPG/ FAPEX), Salvador, $144 \mathrm{p}$.

Cunha, I.A. and Misi, A. (1995) Caracterização petrográfica do depósito de Pb-Zn de Morro Agudo, Minas Gerais. Proc. $48^{\circ}$ Reunião Anual da Sociedade Brasileira de Progresso em Ciências, PUC-São Paulo, v. 2, p. 553.

Daitx, E.C. (1996) Origem e evolução dos depósitos sulfetados tipo-Perau (Pb-Zn-Ag), com base nas jazidas Canoas e Perau (Vale do Ribeira, Paraná).Unpublished Doctorate Thesis, Universidade Estadual Paulista, Instituto de Geociências e Ciências Exatas, Rio Claro, $453 \mathrm{p}$.

Dardenne, M.A. (1976) Geologia da região de Morro Agudo, Minas Gerais. Unpublished report, Universidade de Brasília, Brasília (DF), 30p.

Dardenne, M. (1978a) Les minéralisations de plomb, zinc, fluor du Protérozoique Supérieur dans le Brésil Central. Unpublished Doctorate Thesis, Univ. de Paris VI, France, $251 \mathrm{p}$.

Dardenne, M. (1978b) Síntese sobre a estratigrafia do Grupo Bambuí no Brasil Central. Proc.: Congresso Bras.Geologia, 31, Soc. Bras. Geologia, Recife, v. 2, pp. 597-610.

Dardenne, M. (1979) A estratigrafia dos Grupos Bambuí e Macaúbas no Brasil Central. Soc. Bras. Geologia, Núcleo Minas Gerais, Bulletin, v.1, pp. 43-52.

Davidson, I., (1985) Estudo do falhamento no Alvo Chumbo. Companiha Baiana de Pesquisa Mineral (CBPM), Salvador, $30 \mathrm{p}$. (Unpublished report)

Espourteille, F. and Fleischer, R.(1988) Mina de Chumbo de Boquira. In: Schobbenhaus, C. and Coelho, C.E.S. (Eds.), Principais Depósitos Minerais do Brasil, Departamento Nacional da Producao Mineral/ Companhia Vale do Rio Doce (DNPM/CVRD), Brasília, v. III, pp.91-99.

Fleischer, R. (1976) A pesquisa de chumbo no Brasil. Proc.: Congresso Brasileiro de Geologia, 29, Sociedade Brasileira de Geologia, v. 1, pp. 19-32.

Franca Rocha, W. J. S. F. and Misi, A. (1992a) Evidências de alteração hidrotermal associada a mineralização de $\mathrm{Pb}, \mathrm{Zn}$ e Ag na Formação Caboclo. Proc.: I Simpósio Regional de Geologia Bahia-Sergipe, Sociedade Brasileira de Geologia, Núcleo BA-SE, Salvador, pp. 145-149.

Franca Rocha, W. J. S. F. and Misi, A. (1992b) Mineralizações de sulfetos do tipo sedimentar-exalativo na Formação Caboclo (Proterozóico Médio), Bahia. Proc: Congresso Brasileiro de Geologia, 37, Sociedade Brasileira de Geologia, São Paulo, Bol. Resumos, v.1, pp.254-256.

Franca Rocha, W. J. S. F. and Misi, A. (1993) Estilo tectônico associado às mineralizações do tipo SEDEX nas coberturas do Proterozóico médio do Craton do São Francisco. Proc.: II Simpósio sobre o Craton do São Francisco SBG/SGM, Salvador, Brazil, pp. 340-343.
Franca Rocha, W.J.S.F. (1995) Origem das mineralizações sulfetadas nos sedimentos mesoproterozóicos da borda norte da Chapada Diamantina, Bahia. Unpublished Masters Thesis, Post Graduate Course in Geology, Universidade Federal da Bahia (UFBA), Salvador, Brazil. 132 p.

Gale, G.H. (1983) Proterozoic exhalative massive sulfide deposits. Geol. Soc. of America, Memoir, v.161, pp.191-207.

Gomes, A.S.R. (1998) As mineralizações de sulfetos de $\mathrm{Pb}-\mathrm{Zn}$ de Nova Redenção, Bacia de Una-Utinga, Bahia. Unpublished Masters Thesis, Post Graduate Course in Geology, Universidade Federal da Bahia (UFBA), Salvador, Brazil. 112 p.

Gulson, B.L. (1986) Lead Isotopes in Mineral Exploration. Amsterdam-New York, Elsevier, 245 p.

Iyer, S.S. (1984) A discussion on the lead isotope geochemistry of galenas from the Bambui Group, Minas Gerais- Brazil. Mineralium Deposita, v.19, pp. 132-137.

Iyer, S.S., Hoefs, J. and Krouse, H.R. (1992) Sulfur and lead isotope geochemistry of galenas from the Bambui Group, Minas Gerais, Brazil - Implications for ore genesis. Econ. Geol, v. 87, pp. 437-443.

Kiang, H.C.; Miranda, F.P.; Magalhães, L.; Alkmim, F.F. (1988) Considerações sobre a evolução tectônica da Bacia do São Francisco. Proc.: Congresso Brasileiro de Geologia 35, Sociedade Brasileira de Geologia, Belém, v.5, pp. 2076-2090.

Kyle, J.R. and Misi, A. (1997) Origin of Zn-Pb-Ag sulphide mineralization within Upper Proterozoic phosphate-rich carbonate strata, Irecê Basin, Bahia, Brazil, Intern. Geol. Rev. v. 39, pp. 383-399.

Leach, D.L. and Sangster, D.F. (1993) Mississipi Valley-type leadzinc deposits. In: Kirkham, R.V., Sinclair, W.D., Thorpe, R.I. and Duke, J.M. (Eds.), Mineral Deposits Modeling, Geol. Assoc. of Canada, Special Paper 40, pp. 289-314.

Large, D.E. (1983) Sediment-hosted massive sulphide lead-zinc deposits: an empirical model. In: D.F.Sangster ed., Short Course in sediment-hosted stratiform lead-zinc deposits, Miner. Ass. of Canada, v.8, pp.1-29.

Marini, O.J., Fuck, R.A., Danni, J.C.M., Dardenne, M.A., Loguercio, S.O.C. and Ramalho, R. (1984) As faixas de dobramentos Brasília, Uruaçu e Paraguai-Araguaia e o Maciço Mediano de Goiás. In: C. Schobbenhaus, D.A. Campos, G.R. Derze and H.E. Asmus (Eds), Geologia do Brasil. Texto Explicativo do Mapa Geológico do Brasil e da Área Oceânica Adjacente Incluindo Depósitos Minerais. Ministério da Minas e Energia/Departamento Nacional da Produção Mineral, Brasília, pp. 251-303.

Misi, A. and Kyle, R. (1994) Uper Proterozoic carbonate stratigraphy, diagenesis and stromatolitic phosphorite formation, Irecê Basin, Bahia, Brazil. Jour. Sed. Research, A64, (2), pp.199-310.

Misi, A., lyer, S.S. and Tassinari, C.C.G., (1996) Boquira (2.5 Ga) and Morro Agudo (0.65 Ga) lead-zinc deposits, Brazil: New SEDEX sub-types? Proc. XXXIX Congresso Brasileiro de Geologia, Sociedade Brasileira de Geologia, Salvador, v. 7, pp. 251-253.

Misi, A., Veizer, J., Kawashita, K. and Dardenne, M.A. (1997) The age of the Neoproterozoic carbonate platform sedimentation based on ${ }^{87} \mathrm{Sr} /{ }^{86} \mathrm{Sr}$ determinations, Bambuí and Una Groups, Brazil. South American Symposium on Isotope Geology, Campos do Jordão, São Paulo, Extended Abstracts, pp. 199-200. 
Misi, A. (1978) Ciclos de sedimentação e mineralizações de Pb$\mathrm{Zn}$ nas sequências Bambuí (Supergrupo São Francisco), Estado da Bahia. Proc.: Congresso Bras. de Geologia, 30, Soc. Brasileira de Geologia, Recife, v.4, pp. 2548-2561.

Misi, A. and Silva, M.G. (1996) Chapada Diamantina Oriental, Bahia. Geologia e Depósitos Minerais. Superintendência de Geologia e Recursos Minerais/Universidade Federal da Bahia, Salvador, $194 \mathrm{p}$.

MMAJ-JICA (1983) Report on Geological Survey of Anta Gorda, Brazil: Phase III. Acordo Coop. Tecn. Brasil-Japão, DNPM/ MMAJ, Tokyo, 111 p. (Unpublished report).

Monteiro, M.D., Silva, A.B., Carvalho, M.P., Froes, RJ.B. and Souza, S.L.(1987) Projeto Irecê-Lapão, Campanhia Baiana de Pesquisa Mineral (CBPM), Salvador, v. 1 (Unpublished report).

Monteiro, M.D. (1989) Projeto Irecê-Lapão, 2a etapa, reprogramação. Secretaria das Minas e Energia/Companhia Baiana de Pesquisa Mineral (SME/CBPM), 2 volumes . (Final Report).

Moraes Filho, O. and Leal, R.A. (1990) Prospecção de chumbo/ zinco/prata no município de Nova Redenção (BA). Proc.: Congresso Brasileiro de Geologia, 36, Sociedade Brasileira de Geologia, Natal, pp.1407-1501.

Neves, J.P., Santana A.C., Silva, J.F., Casé, M.G. and Bruni, D.C. (1980) Projeto Caboclo. Companhia de Pesquisa de Recursos Minerais (CPRM), Salvador, 3 vol. (Unpublished report).

Ohmoto, H., and Rye, R.O. (1979) Isotopes of sulphur and carbon, In: Barnes, H.L. (Ed.), Geochemistry of Hydrothermal Ore Deposits, New York, Wiley-Interscience, pp. 509-567.

Pedrosa Soares, A.C., Noce, C.M., Vidal, P., Monteiro, R.L.B.P. and Leonardos, O.H. (1992) Toward a new tectonic model for the Upper Proterozoic Araçuai (SE Brazil) - West Congolian (SW Africa) Belt. J. South Amer, Earth Sci.,v. 6(1/ 2), pp.33-47.

Remus, M.V.D., McNaughton, N.J., Hartmann, L.A., Groves, D.l. and Reischl, J.L. (1997) $\mathrm{Pb}$ and $\mathrm{S}$ isotope signature of sulfides and constraints on timing and sources of $\mathrm{Cu}(\mathrm{Au})$ mineralization at the Camaquã and Santa Maria mines, Caçapava do Sul, Southern Brazil. South American Symposium on Isotope Geology, Campos do Jordão, São Paulo, Extended Abstracts, pp. 253-255.
Rigobello, A.E., Branquinho, J.A., Dantas, M.G.S., Oliveira, T.F. and Neves Filho, W. (1988) Mina de zinco de Vazante. In: C. Schobbenhaus and C.E. Coelho (Eds), Principais Depósitos Minerais do Brasil, Departamento Nacional da Produção Mineral/Companhia Vale do Rio Doce (DNPM/ CVRD), v. 3, pp. 101-110.

Rocha, G.M.F. (1990) Caracterização da fácies ferrífera de Boquira - encaixante da mineralização de chumbo-zinco. In: J.F. Mascarenhas (Ed.), Geologia e Recursos Minerais do Estado da Bahia. Textos Básicos, SME/SGM, Salvador, BA, v. 8, pp. 9-75.

Romagna, G. and Costa, R.R. (1988) Jazida de zinco e chumbo de Morro Agudo, Paracatú, Minas Gerais. In: C. Schobbenhaus and C.E. Coelho (Eds), Principais Depósitos Minerais do Brasil, Departamento Nacional da Produção Mineral/Companhia Vale do Rio Doce (DNPM/CVRD), v. 3, pp. 111-121

Romagna, G. and Costa, R.R. (1989) The Morro Agudo zinc and lead ore deposit, Paracatu, Minas Gerais. Excursion Guide: International Geochemical Congress, Soc. Bras. Geoquímica, Brasília, pp. 149-163.

Stacey, J.S. and Kramer, J.D. (1975) Approximation of terrestrial lead isotope evolution by a two-stage model. Earth and Planet. Sci. Lett., v. 26, pp. 207-221.

Strauss, H. (1993) The sulphur isotopic record of Precambrian sulfates: New data and critical evolution of existing record: Precamb. Res., v. 63, pp. 225-246.

Tassinari, C.C.G., Barbour, A., Daitx, E. and Sato, K. (1990) Aplicação dos isótopos de $\mathrm{Pb}$ e $\mathrm{Sr}$ na determinação da natureza das fontes das mineralizaçōes de chumbo do Vale do Ribeira, São Paulo e Paraná. Proc.: Congresso Brasileiro de Geologia, 36 Soc. Bras. Geologia, Natal, RN, v. 3, pp. 1254-1266.

Veizer, J. and Hoefs, J. (1976) The nature of ${ }^{18} \mathrm{O} /{ }^{16} \mathrm{O}$ and ${ }^{13} \mathrm{C} /$ ${ }^{12} \mathrm{C}$ secular trends in sedimentary carbonate rocks. Geochim. Cosmochim. Acta, v. 40, pp. 1387-1395.

Veizer, J., Clayton, R.N., Hinton, R.W., Von Brun, V., Mason, T.R. and Hoefs, J. (1990) Geochemistry of Precambrian carbonates: 3 - Shelf sea and non-marine environments of the Archean. Geochim. Cosmochim. Acta, v.54, pp. 27172729.

Zartman, R.E. and Doe, B.R (1981) Plumbotectonics - the model. Tectonophysics, v. 75, pp.135-62. 